\title{
Evolution of the middle crust of the Pyrenees during the Paleozoic: new data on the plutonic rocks from the North Pyrenean Agly Massif
}

\author{
B. Tournaire Guille ${ }^{1} \cdot$ Ph. Olivier ${ }^{2,3}$ (D) J. -L. Paquette ${ }^{4} \cdot$ V. Bosse $^{4} \cdot$ D. Guillaume ${ }^{5}$
}

\begin{abstract}
The Variscan middle crust of the eastern Pyrenees is represented by the Bélesta and Caramany gneissic units of the North Pyrenean Agly Massif. In this study, we date and reinterpret the orthogneisses and granites composing these units. We characterize a recurrent plutonic activity spanning all the Paleozoic in this part of the Pyrenean crust. The Bélesta unit (amphibolite facies) is mainly composed of sills of (Latest Ediacaran)-Earliest Cambrian (542 \pm 4 and 540 $\pm 4 \mathrm{Ma}$ ) orthogneisses (70\% of the series), almost unknown in the Pyrenees until now, and Latest Carboniferous-(Earliest Permian) (307 $\pm 3-298 \pm 3$ Ma time span) granites (15\% of the series). These plutonic rocks were emplaced in probably Ediacaran aluminous pelites later transformed into paragneisses (15\% of the series). The Caramany unit (granulite facies) is mainly composed of Precambrian aluminous paragneisses migmatized during the Latest Carboniferous-(Earliest Permian) (299 \pm 4 Ma), sills of Earliest Cambrian (529 $\pm 5 \mathrm{Ma}$ ) orthogneisses and sills (about 30\% of the series) of Late Carboniferous (308 $\pm 3-299 \pm 3 \mathrm{Ma}$ ) opxbearing and opx-free granodiorites, grt-bearing leucogranites and norites. Among these last rocks, the Ansignan charnockite, forming a $800 \mathrm{~m}$-thick laccolith near the base of the Caramany unit, and previously dated at $314 \pm 6 / 7 \mathrm{Ma}$ (Respaut, Lancelot, Neues Jahrbuch Miner Abh 147-1:21-34, 1983), is refined at 307 \pm 3 Ma. Our results confirm the importance of the Late Carboniferous plutonism in deep levels of the Pyrenean crust, which largely resulted from recycling of older para- and orthoderived rocks of this crust. The emplacement of hundreds of metres in thickness of granites and other plutonic rocks in the Variscan Pyrenees occurred in a rather short time both as sills in these deep levels and as large plutons in shallower levels, a fact which necessarily had consequences on the HT-LP Carboniferous metamorphism.
\end{abstract}

Keywords Variscan Pyrenees · North Pyrenean Agly Massif · Orthogneiss · Granite · Ediacaran · Earliest Cambrian · Late Carboniferous $\cdot$ Crust recycling $\cdot$ Partial melting

Ph. Olivier

philippe.olivier1531@ orange.fr

1 iSTeP-UMR 7193, Université Pierre et Marie Curie-P6, 4 place Jussieu, 75252 Paris Cedex 05, France

2 Géosciences Environnement Toulouse (GET) and UMR 5563, Université de Toulouse, CNRS, IRD, OMP, 14 Avenue E. Belin, 31400 Toulouse, France

354 Impasse de la Bergeronnette, 31240 L'union, France

4 Laboratoire Magmas et Volcans, Université Clermont Auvergne, CNRS, IRD, OPGC, 63000 Clermont-Ferrand, France

5 Université Lyon, UJM-Saint-Etienne, UCA, CNRS, IRD, LMV UMR 6524, 42023 Saint-Etienne, France

\section{Introduction}

The evolution of the deep parts of modern chains may hardly be studied, because the crust cannot be observed directly and the stages of this evolution, for instance the emplacement of plutonic rocks, are very slow phenomena. Only ancient chains, deeply eroded, may provide specific data related to their evolution (e.g., Linnemann et al. 2008; Lardeaux 2014; Couzinié et al. 2017). Even when such data are available, unraveling the various events which characterized this evolution is complicated, because precise ages of all the rocks constituting the crust are often unknown. Another problem is to determine the volume balance between the initial state of the crust and the final state, i.e., whether the plutonic rocks were emplaced directly from the upper mantle and/or were fed by recycling parts of the crust itself, for instance between the lower crust and the middle crust (e.g., He and Santosh 
2014; Moyen et al. 2017; Safonova 2017). This question needs detailed chemical analyses whose interpretation is often questionable.

The Pyrenean range (Fig. 1a) was formed by the Late Cretaceous-Eocene collision of the Iberian and European plates, but a large part of this chain is constituted by Precambrian and Paleozoic metamorphic and plutonic rocks which represent remnants of the upper and middle crust of the West European Variscan orogen. These formations are particularly suitable for addressing the question of the crust evolution by successive emplacements of plutonic rocks. In this paper, we characterize and date the various plutonic events which occurred not only during the Variscan orogeny but during all the Paleozoic times, taking the North Pyrenean Agly massif as a case study, because Paleozoic rocks are largely exposed and represent a natural cross section from the base of the middle crust to the upper crust.

\section{Geologic setting}

The Pyrenees are classically subdivided into three main E-W-trending zones, mainly on the basis of their contrasting Cretaceous evolutions. From north to south these zones are the North Pyrenean Zone, the Axial Zone and the South
Pyrenean Zone. The North Pyrenean Zone and the Axial Zone are separated by the North Pyrenean Fault, a major crustal-scale fault (Fig. 1a).

Owing to the formation of gneiss domes by the end of the Carboniferous time, and more recent tilting, Paleozoic and Precambrian formations may be widely observed in various parts of the Pyrenees, especially in the North Pyrenean Agly Massif (Eastern Pyrenees) (Fonteilles 1976; Delay 1990; Fonteilles et al. 1993; Berger et al. 1993) (Fig. 1b), which displays a cross section from the upper crust to the base of the middle crust (Olivier et al. 2008).

In the Agly Massif, three main lithologic units are observed, from top to bottom (Fig. 2, cross sections AA' $^{\prime}$ and $\left.\mathrm{BB}^{\prime}\right)$ :

1. A low- to medium-grade metasedimentary unit (greenschist to amphibolite facies), the 'Caladroy-Força Real unit' ('Col de la Bataille' and 'Força Real' units in Berger et al. 1993), whose protolith is essentially Cambrian (?) to Ordovician (up to reduced Carboniferous formations) in age, and composed of metapelites and metagraywackes. This series was intruded by a probably Ordovician granitic laccolith (Rivérole orthogneiss), a Late Carboniferous granitic pluton (Saint-Arnac pluton) (Olivier et al. 2008) and pegmatite dykes;

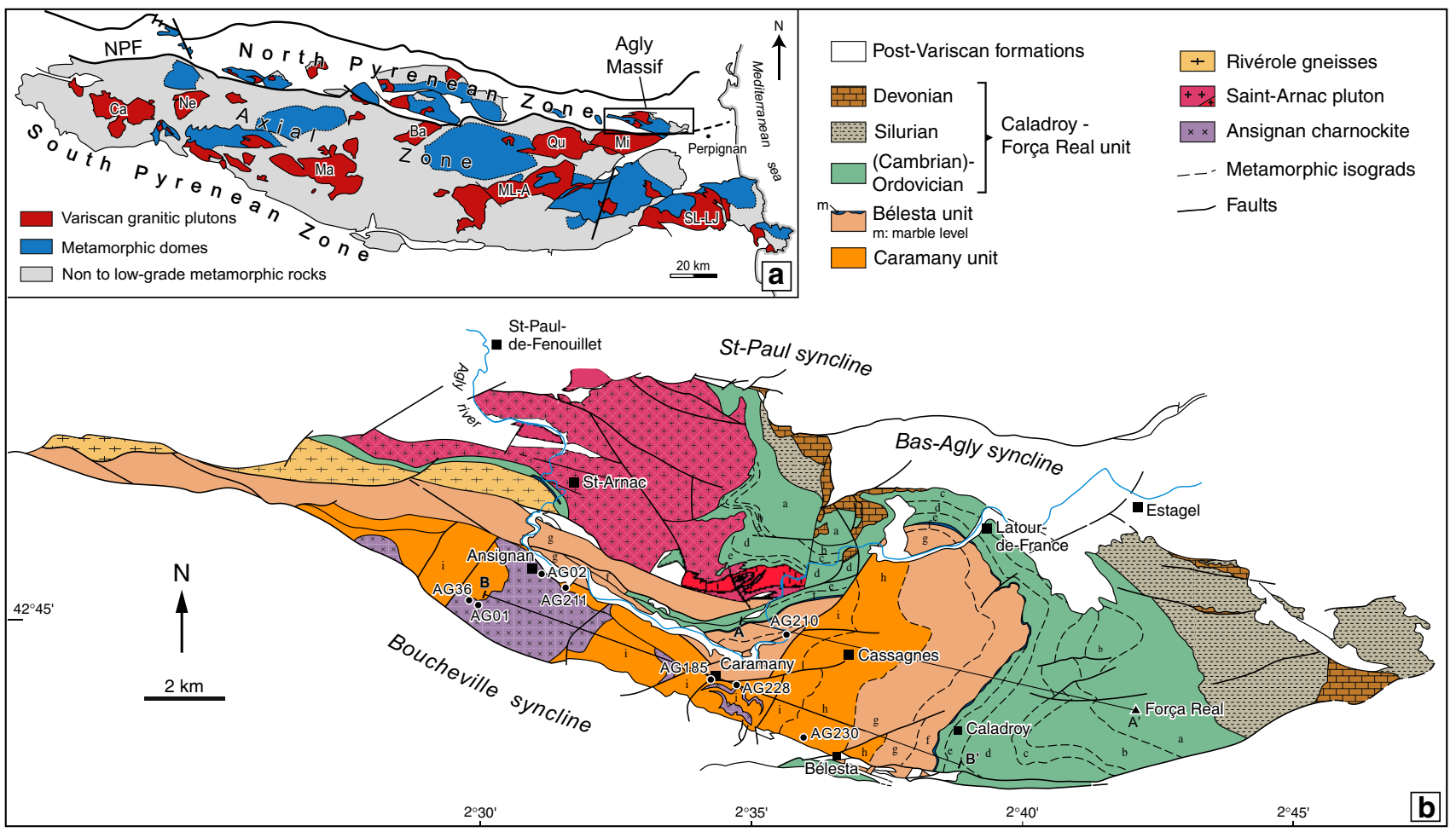

Fig. 1 a Variscan Pyrenees. b Agly Massif, with location of the studied samples (AG) and of the two cross sections $\mathrm{AA}^{\prime}$ and $\mathrm{BB}^{\prime}$ of Fig. 2. Metamorphic zones: $a=$ chlorite, $b=$ biotite, $c=$ cordierite, $\mathrm{d}=$ andalusite, $\mathrm{e}=$ sillimanite + muscovite, $\mathrm{f}=$ sillimanite $+\mathrm{K}$-feldspar, $\mathrm{g}=$ cummingtonite, $\mathrm{h}=$ hypersthene + hornblende, $\mathrm{i}=$ hypersthene 

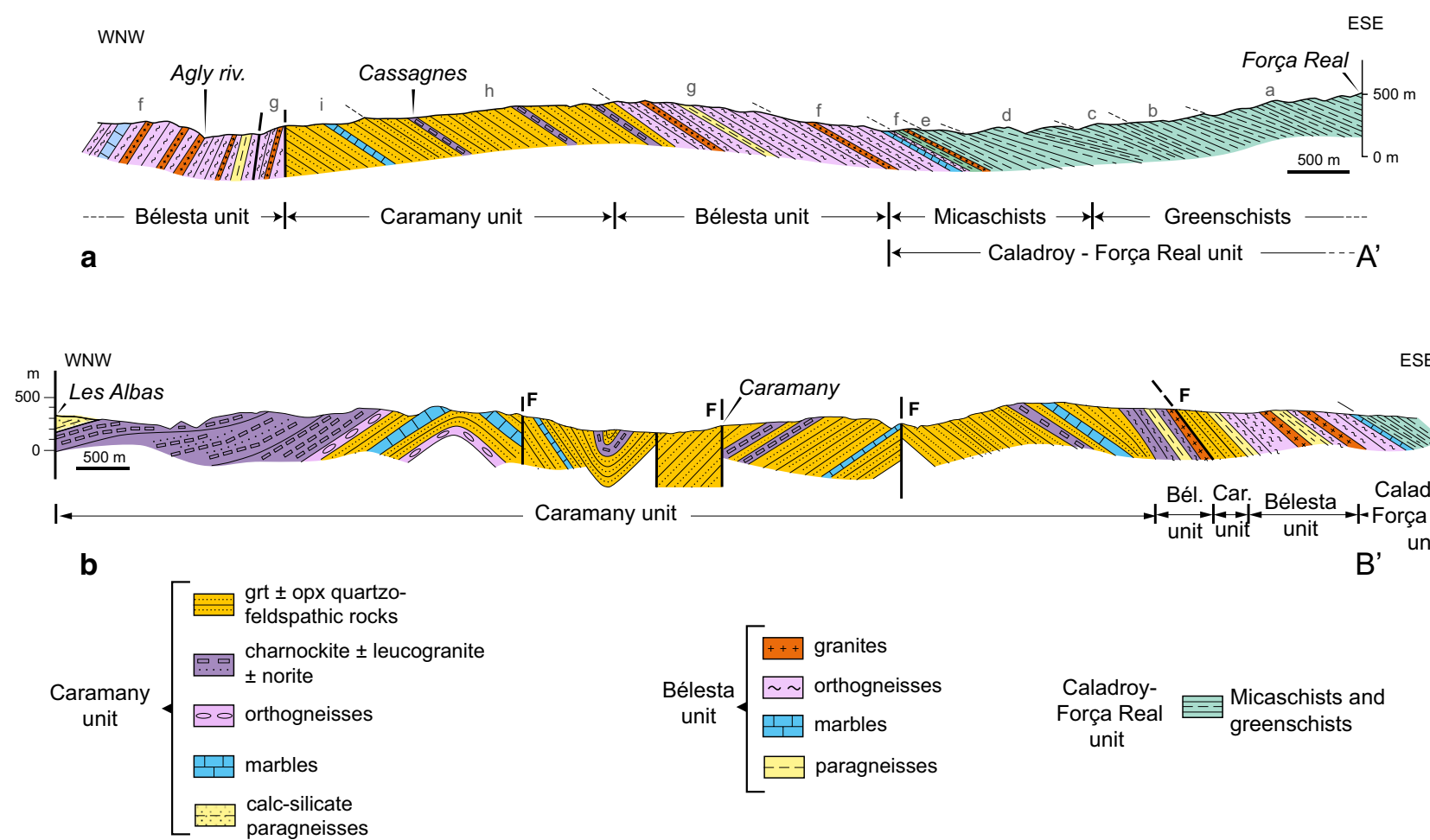

Fig. 2 Cross sections (AA' and $\left.\mathrm{BB}^{\prime}\right)$ through the Caladroy-Força Real, Bélesta and Caramany units. a-i Metamorphic zones as indicated in Fig. 1

2. A high-grade (amphibolite facies) unit, the 'Bélesta unit' [= 'Gneiss de Bélesta' in Berger et al. (1993)], which consists of partly migmatized paragneisses and orthogneisses, intruded by granitoids and pegmatites;

3. A low-pressure, high-grade (granulite facies) unit, the 'Caramany unit' [= 'Gneiss de Caramany' in Berger et al. (1993)], which consists of paragneisses, marbles, orthogneisses and various granitoids, the most mafic granitoids containing hypersthene (charnockites). Sills of norite are locally associated with the charnockites.

These three units were variously mylonitized at high temperature, possibly by the end of the Variscan orogeny, after the emplacement of the youngest plutonic rocks (pegmatites). Because of this mylonitization, the present thickness of the massif $(8-9 \mathrm{~km})$ could be less than half the initial thickness (i.e., $20-23 \mathrm{~km}$ ) if the estimations of the pressure conditions of the deepest rocks (Ansignan charnockite) are correct (Andrieux 1982: $6 \pm 1 \mathrm{~kb}$; Vielzeuf 1984, 1996: $5 \pm 0.5 \mathrm{~kb}$ ). This strong thinning of the series, which has brought closer the isograds, may partly explain the very high temperature gradient described in the metamorphic rocks of this massif, which consequently is only an apparent gradient.

The Variscan deformation of the Agly massif has been studied by Olivier et al. $(2004,2008)$ who have described the half-dome structure of the massif and determined the characteristics of the main pervasive deformation (WNW-ESE-trending foliation, NNE-SSW stretching lineation indicating a top-to-the-south movement), related to the D1 event known in the whole Pyrenees. The magmatic fabrics of the Ansignan charnockite and the Saint-Arnac granitic pluton are characterized by NE-SW-trending lineations likely related to the $\mathrm{D} 2$ dextral transpressive event. The HT mylonitic deformation, irregularly distributed in the Agly massif, is characterized by generally flat-lying foliations and NNE-SSW stretching lineations corresponding to both northward and southward movements. Dates of various plutonic rocks of the Agly massif were published by Respaut and Lancelot (1983) (314 $\pm 6 / 7$ Ma for the Ansignan charnockite) and by Olivier et al. $(2004,2008)(308 \pm 1 \mathrm{Ma}$ for the diorite forming the base of the Saint-Arnac pluton; $304 \pm 5 \mathrm{Ma}$ and $307 \mathrm{Ma}$ for two granodiorites forming the main part of this pluton; $317 \pm 3$ Ma for a granitic sill from the upper part of the Bélesta unit).

This study is based on new dating of granitoids and orthogneisses of the Bélesta and Caramany units. We have especially studied in great detail a $50 \mathrm{~m}$-long continuous cross section from the Bélesta unit, with rocks particularly fresh because of excavation works made for a dam on the Agly river in the 1990'. This cross section allows the observation of the various rocks of this unit, their relationships and their respective ages and proportion. Our results from 
the Caramany and Bélesta units allow the characterization of the various stages of plutonic inputs in this part of the Pyrenean crust during the whole Paleozoic.

\section{The Bélesta unit}

According to Berger et al. (1993) this unit would be mainly composed of a 1000 m-thick series of quartzofeldspathic paragneisses, Late Proterozoic in age. However, we show below that the nature and age of these gneisses must be deeply reconsidered.

\section{Petrostructural description of the Agly dam cross section (AG210 samples in Fig. 1b)}

From north (upper part) to south (lower part) this cross section shows an alternation of sub-vertical E-W trending (azimuth N65-N95E, dip 70 to the north, to vertical) decimetre- to pluri-metre-thick sheets of gneisses and granitoids, precisely measured perpendicularly to the boundaries between the various sheets (Fig. 3). The series is not affected by visible folds. The contacts between the different rock types are either progressive from one to another type of orthogneiss, or sharp and magmatic between the granites and the orthogneisses or paragneisses. The paragneisses do not display evidences of partial melting, whereas the orthogneisses do display such evidences, characterized by disorganized foliations, near the granitic sheets (photo $6 \mathrm{~b}$ in Fig. 3). At a distance (some dcm) from the granitic sheets the orthogneisses of this cross section display a regular gneissic foliation. The granitic sheets correspond to intrusions within these orthogneisses and not to in-situ leucosomes, because the contact between both rock types is sharp and not progressive. However, these granitic intrusions might have been produced by partial melting of rather neighbouring similar orthogneisses, as suggested by the granitic "bubble" shown on photograph $6 \mathrm{~b}$ of Fig. 3 which was probably produced in-situ (fuzzy contacts with the orthogneiss). Note that the dark streaks within the granitic intrusion AG210I are not schlieren (i.e., flow-induced trains of biotite), but non-displaced fine remnants of the orthogneiss within which the granite was intruded.

Three main types of rocks constitute this cross section: (1) probable paragneisses (ca $15 \%$ of the cross section) characterized by continuous thin layers of millimetre- to centimetre-scale crystals of quartz, K-feldspar, plagioclase and biotite, in various proportion, containing also abundant aluminous minerals (sillimanite, garnet, cordierite); (2) orthogneisses (ca $70 \%$ of the cross section), generally containing centimetre- to pluricentimetre-scale porphyroclasts of K-feldspar with the Carlsbad twin, the gneissic foliation
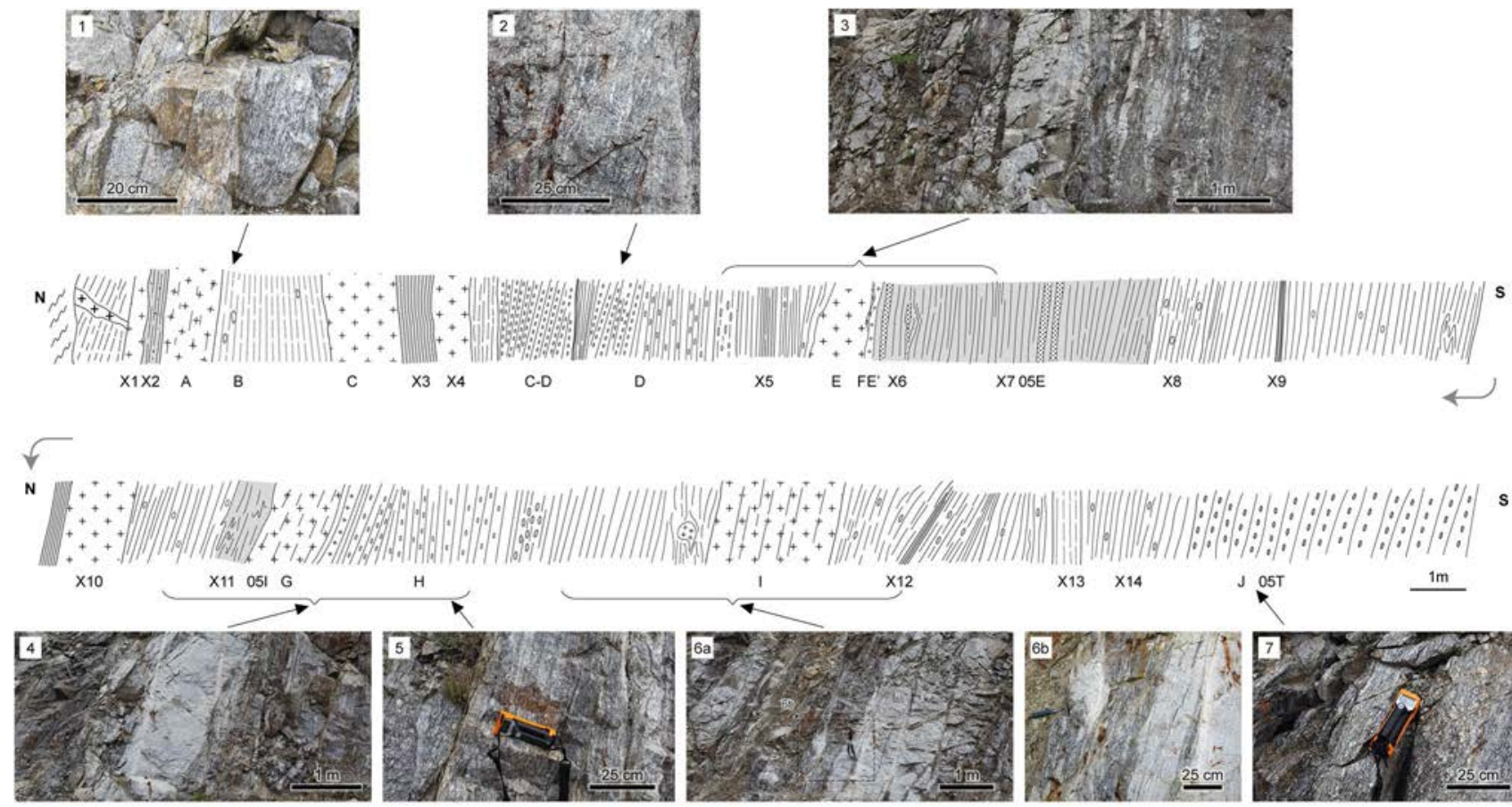

Paragneisses
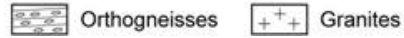

Pegmatite

Fig. 3 Agly dam cross section in the Bélesta unit (samples AG210A-J, AG210X1 to X14, AG05E, I and T). To be read from north (top left) to south (bottom right). Photographs 1-7 represent more or less close views of the paragneisses, orthogneisses and granites of this cross section 
being underlined by continuous layers of biotite; (3) biotite \pm muscovite granites (ca $15 \%$ of the cross section) with a magmatic foliation, marked by discontinuous alignments of biotite, parallel to the foliation of the gneisses. Some of these rocks are slightly mylonitized but the series has not been significantly thinned by late deformation on this cross section (no mylonitic band was observed), and the contacts between the various rock types have not been affected by this mylonitization.

A first set of samples is labelled AG210A-AG210J. Two complementary sets of samples are labelled AG210X1 to AG210X14 and AG05E, AG05I and AG05T (Fig. 3).

A brief description of most of the samples, from thin sections, is given in Table 1, and representative microphotographs of the orthogneisses (AG210B and AG210J) and granites (AG210E and AG210G) are presented in Fig. 4. The phase assemblages of both the orthogneisses and the granites are rather similar, only the textures being different. In the orthogneisses, which show well defined foliations and lens-shaped K-feldspars on the outcrop, the biotite is recrystallized and forms more or less continuous levels; quartz is largely recrystallized into small grains. The granites display typical magmatic to submagmatic textures, and the mica flakes are generally scattered; muscovite is secondary, as well as a unique crystal of andalusite observed in AG210G; sillimanite and garnet may be found in these granites but are rather rare, especially compared to the paragneisses. An incipient solid-state deformation, especially characterized by recrystallization of quartz grains, may be observed on these granites but the primary texture is generally still visible. The paragneisses are characterized by a very conspicuous foliation, especially marked by thin bands of biotite and sillimanite, and the quartz is completely recrystallized.

\section{Chemical composition of gneisses and granites of the Agly dam cross section}

Five samples from this cross section (two granites, two orthogneisses, one paragneiss) were analyzed for major and trace elements (Table 2). On a Shand diagram (Fig. 5), both the orthogneisses (AG210B and AG05T (=AG210J)) and the granites (AG210E and AG05I (=AG210G)) are peraluminous and plot around the I-type/S-type granites boundary (A/CNK=1.1). On a $\mathrm{Na}_{2} \mathrm{O}+\mathrm{K}_{2} \mathrm{O}$ vs. $\mathrm{SiO}_{2}$ diagram (Fig. 6), the orthogneisses and granites belong to the calc-alkaline(subalkaline) domain. These orthogneisses and granites show very similar multi-element mantle-normalized spectra with $\mathrm{Ta}-\mathrm{Nb}, \mathrm{Sr}, \mathrm{P}$ and Ti negative anomalies (Fig. 7a). The REE patterns (Fig. 7b) are fractionated, and similar for AG05I granite and AG210B and AG05T orthogneisses ([La/ $\mathrm{Yb}]_{\mathrm{N}}=12.14,10.35$ and 15.45 , respectively), with a clear negative $\mathrm{Eu}$ anomaly. However, heavy REE are more fractionated for the AG210E granite sample $\left([\mathrm{La} / \mathrm{Yb}]_{\mathrm{N}}=29.56\right)$.
The paragneiss (AG05E) is more peraluminous $\left(\mathrm{Al}_{2} \mathrm{O}_{3}=15.88 \%\right)$ and poorer in $\mathrm{CaO}(0.55 \%)$ and $\mathrm{Na}_{2} \mathrm{O}$ $(1.89 \%)$ than these granitoids, as expected from its paragenesis; it displays $\mathrm{FeO}$ and $\mathrm{MgO}$ contents $(3.45 \%$ and $1.05 \%)$ similar to the AG210B orthogneiss (3.81\% and 1.10\%), and higher than the other granitoids; it displays $[\mathrm{La} / \mathrm{Yb}]_{\mathrm{N}}=8.33$ lower than the granitoids (see Table 2).

\section{$\mathrm{U} / \mathrm{Pb}$ dating of rocks of the Agly dam cross section}

\section{Analytical procedure}

Approximately 50 zircons per sample were mounted in epoxy disks and ground and polished to expose crystal interiors. U-Th- $\mathrm{Pb}$ isotope data were measured by laser ablation inductively coupled mass spectrometry (LA-ICP-MS) at LMV (Clermont-Ferrand, France). Zircons were ablated using a Resonetics Resolution M-50 equipped with a $193 \mathrm{~nm}$ Excimer laser system coupled to an Agilent $7500 \mathrm{cs}$ ICPMS. Helium carrier gas was supplemented with $\mathrm{N}_{2}$ prior to mixing with Ar for sensitivity enhancement (Paquette et al. 2014). The laser was operated with a spot diameter of $26 \mu \mathrm{m}$, a repetition rate of $3 \mathrm{~Hz}$, and a fluence of $3.5 \mathrm{~J} / \mathrm{cm}^{2}$. The ICPMS was tuned to maximize the ${ }^{238} \mathrm{U}$ intensity and minimize $\mathrm{ThO}^{+} / \mathrm{Th}^{+}(<1.5 \%)$ using the NIST SRM 612 glass standard. The signals of ${ }^{204} \mathrm{~Pb}(+\mathrm{Hg}),{ }^{206} \mathrm{~Pb},{ }^{207} \mathrm{~Pb},{ }^{208} \mathrm{~Pb},{ }^{232} \mathrm{Th}$, and ${ }^{238} \mathrm{U}$ were acquired during each analysis (Hurai et al. 2010). Background levels were measured on-peak with the laser off for $\sim 30 \mathrm{~s}$, followed by $\sim 60 \mathrm{~s}$ of measurement with the laser firing and then $\sim 30 \mathrm{~s}$ of washout time. Reduction of raw data was carried out using the GLITTER $®$ software package of Macquarie Research Ltd (van Achterbergh et al. 2001). Isotope ratios were corrected for laser-induced and instrumental mass fractionation via sample-standard bracketing using the GJ-1 zircon standard (Jackson et al. 2004) which was analyzed four times at the beginning and end of each analytical session, and twice after each set of eight samples. Concentrations of $\mathrm{U}, \mathrm{Th}$, and $\mathrm{Pb}$ were calculated by normalization to the certified composition of GJ-1 (Jackson et al. 2004). Data are not corrected for common Pb. TeraWasserburg ${ }^{207} \mathrm{~Pb} /{ }^{206} \mathrm{~Pb}$ vs. ${ }^{238} \mathrm{U} /{ }^{206} \mathrm{~Pb}$ diagrams were generated for each sample using the Isoplot/Ex v. 2.49 software of Ludwig (2001). Error ellipses for each point are shown at the $2 \sigma$ level and incorporate both internal and external uncertainties. Data points were pooled to calculate a date and associated $2 \sigma$ error for each sample using Isoplot. The Harward 91500 zircon (Wiedenbeck et al. 1995) was analyzed along with the samples, to independently monitor the external precision and accuracy of the measurements. The Concordia age for 38 analyses of 91500 conducted over the course of the study was $1064.9 \pm 4.5 \mathrm{Ma}$ [ $2 \sigma$ including decay constant errors; $\left.\operatorname{MSWD}_{(\mathrm{C}+\mathrm{E})}=0.40\right]$. 


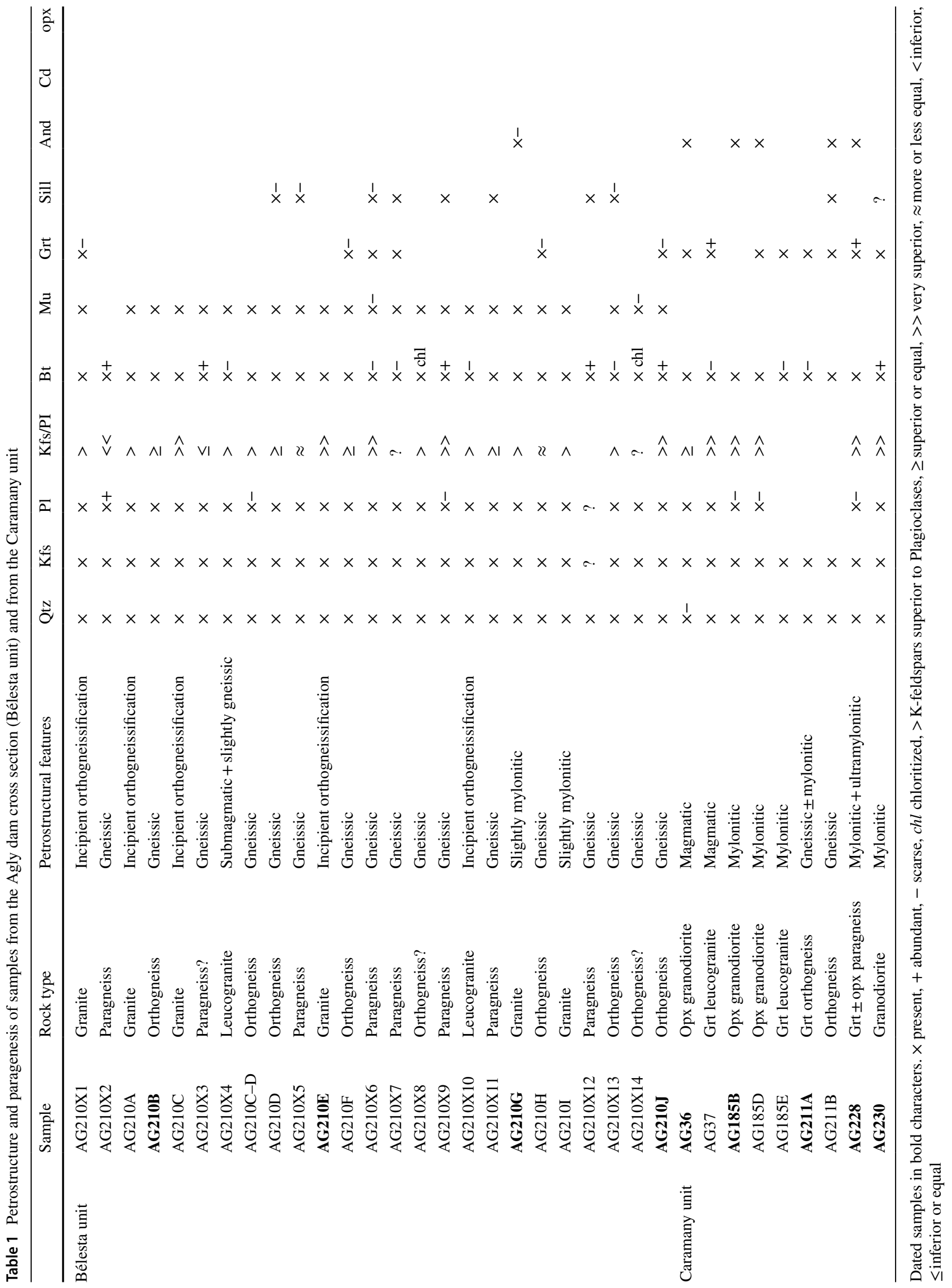


Fig. 4 Microphotographs of the dated orthogneisses (AG210B and $\mathrm{AG} 210 \mathrm{~J}$ ) and granites (AG210E and AG210G) of the Agly dam cross section in the Bélesta unit. In AG210B and $\mathrm{AG} 210 \mathrm{~J}$ orthogneisses the biotite is recrystallized and forms continuous bands and the quartz is largely recrystallized forming continuous bands of small grains. In AG210E granite the magmatic to submagmatic texture is well preserved, the biotite flakes are scattered and not recrystallized, the quartz displays undulatory extinctions or is locally recrystallized into tiny grains. In AG210G granite the quartz is more deformed (incipient mylonitization) but the other minerals are undeformed and a secondary paragenesis with mu+ and appears. and andalusite, $b t$ biotite, $K f s$ $\mathrm{K}$-feldspar, $m u$ muscovite, $p l$ plagioclase, $q t z$ quartz
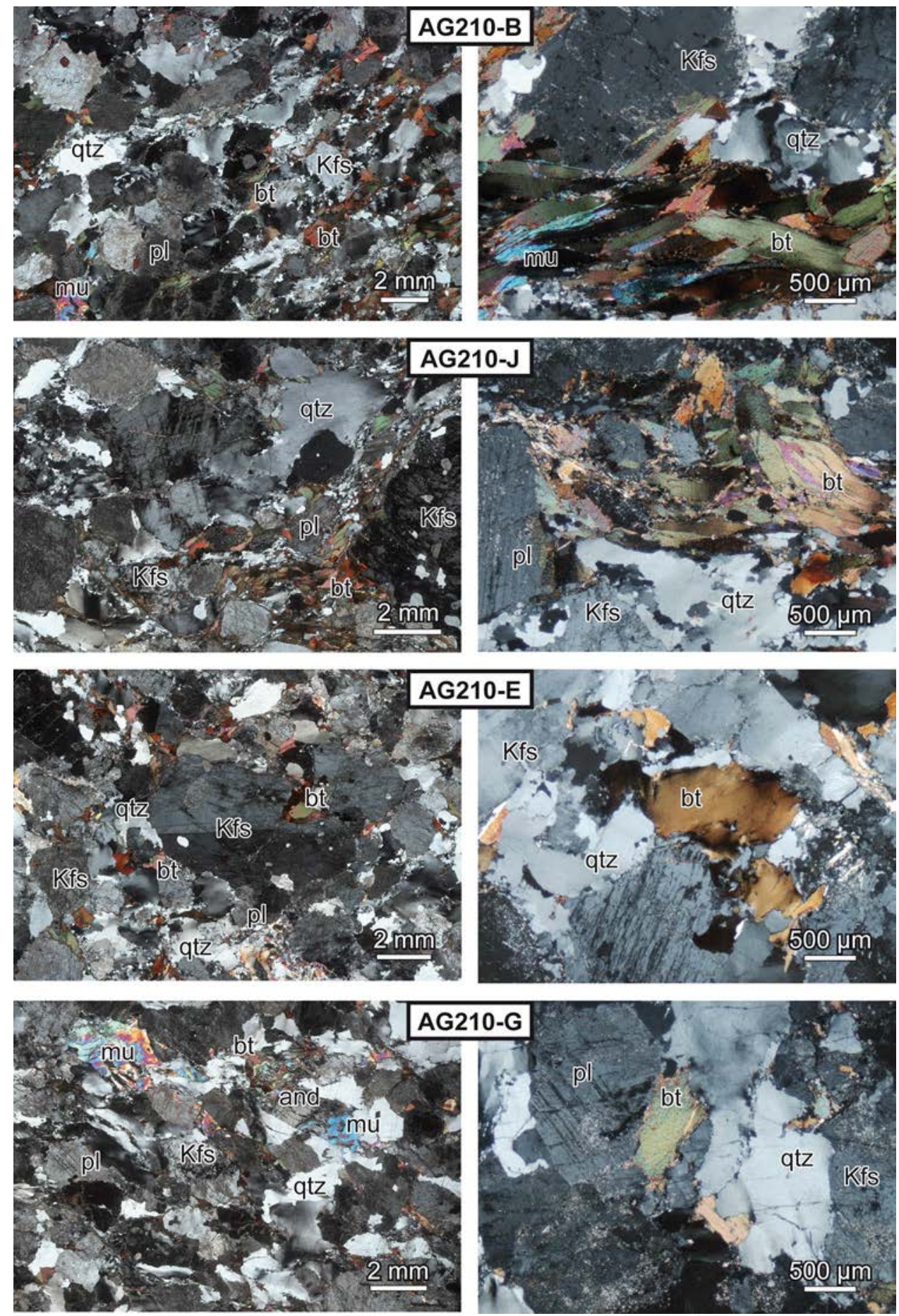

For the Bélesta unit, the dated samples were chosen on the basis of their petrographic aspect, either orthogneissic (AG210B and AG210J) or granitic (AG210E and AG210G), to date the main facies of this cross section. No attempt of dating the paragneisses was made, because the zircons they may contain could just reflect the sedimentary history which is out of the scope of this paper.

\section{Geochronological results}

The results are reported in Fig. 8 and Table 3. AG210B and AG210J orthogneisses yield similar Concordia ages: $541.8 \pm 3.7 \mathrm{Ma}$ (Fig. 8a) and 539.8 $\pm 3.7 \mathrm{Ma}$ (Fig. 8b), respectively, i.e., (Latest Ediacaran)-Earliest Cambrian. Four analytical points of AG210B were affected by Pb-loss 


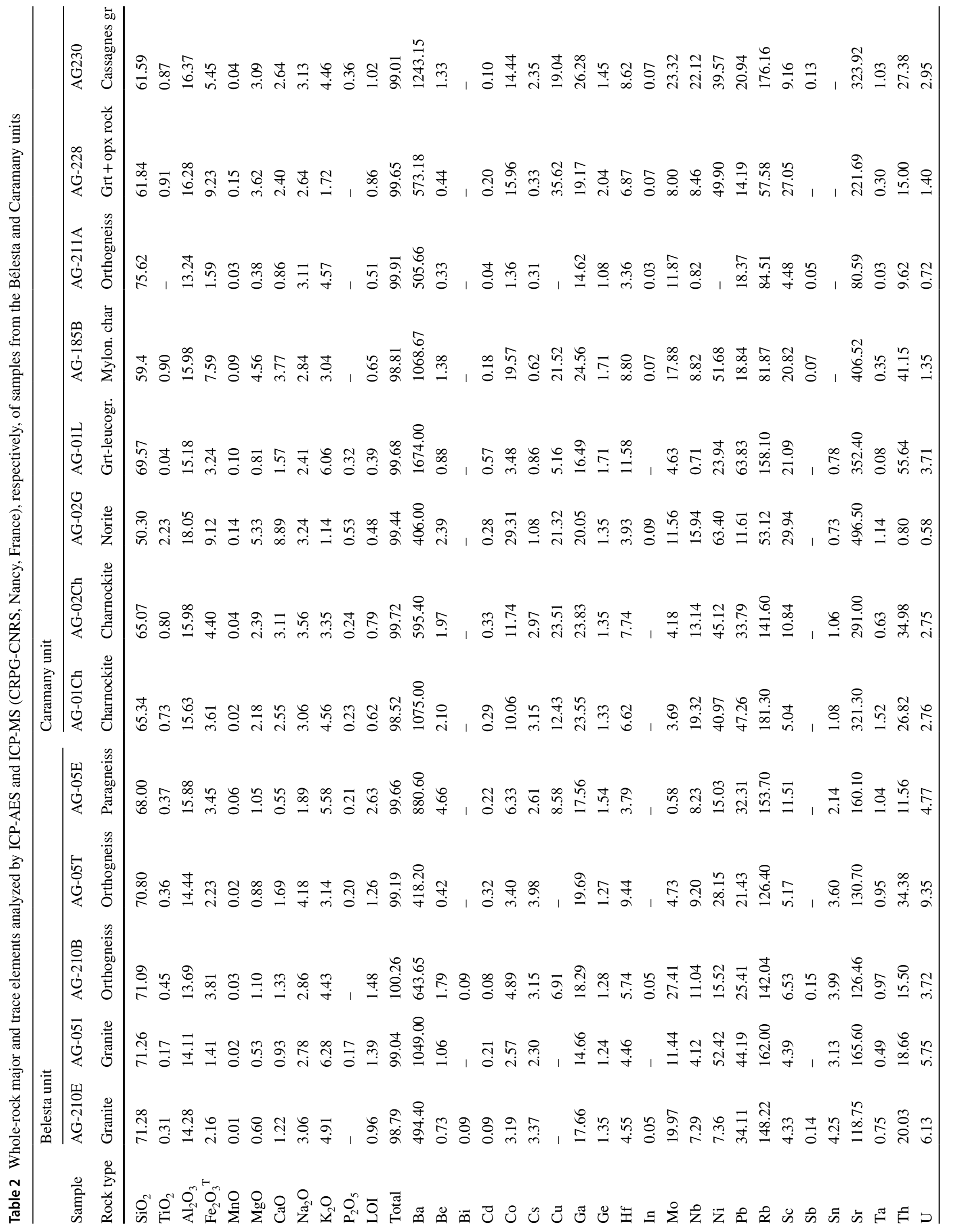




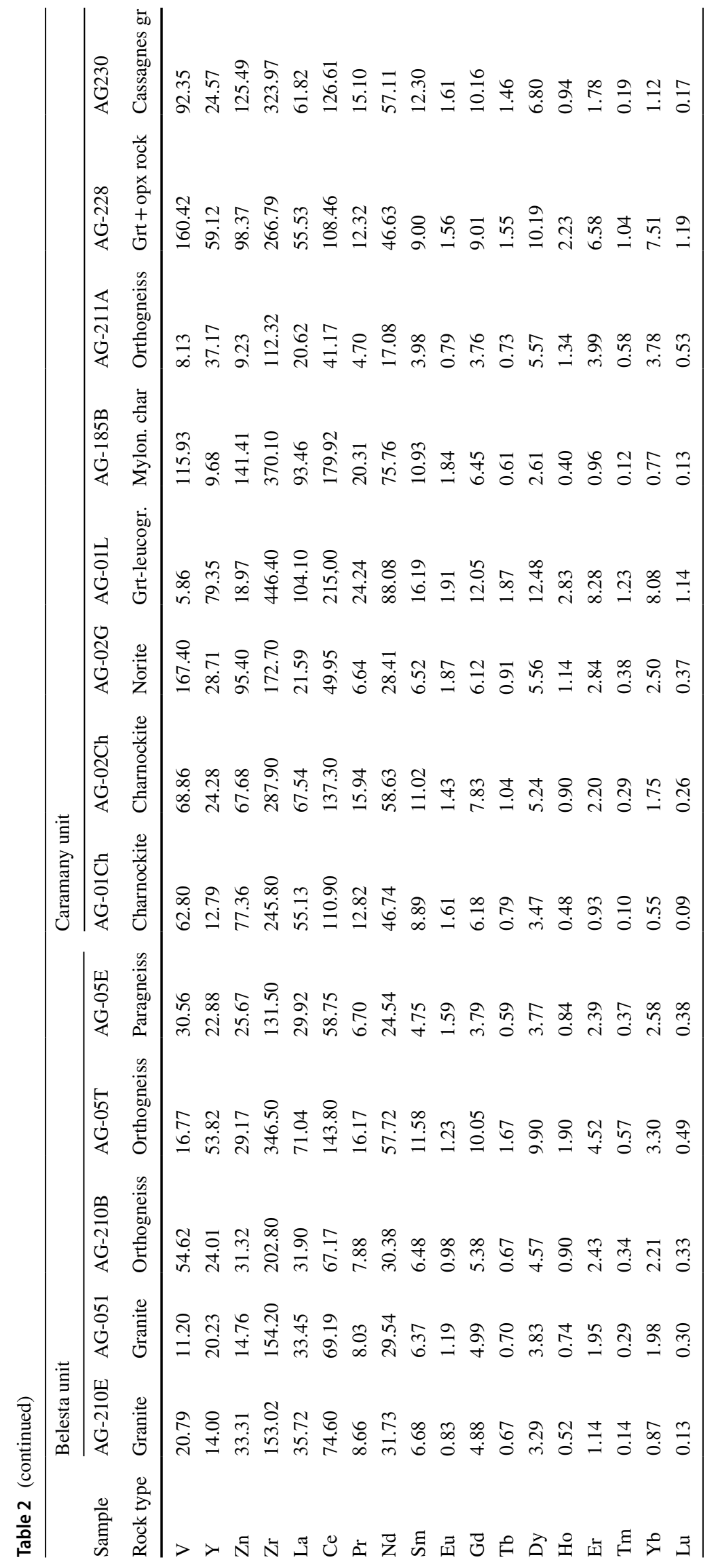




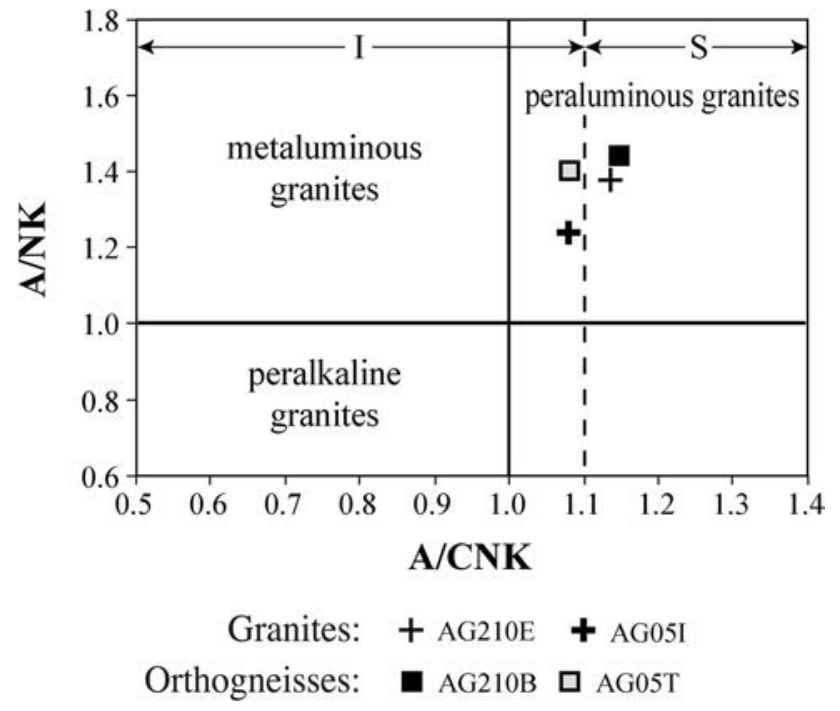

Fig. 5 A/NK vs. A/CNK diagram for the granite (AG210E and AG05I) and orthogneiss (AG210B and AG05T) samples of the Agly dam cross section in the Bélesta unit. $\mathrm{A}: \mathrm{Al}_{2} \mathrm{O}_{3}, \mathrm{C}: \mathrm{CaO}, \mathrm{N}: \mathrm{Na}_{2} \mathrm{O}$ and $\mathrm{K}: \mathrm{K}_{2} \mathrm{O}$
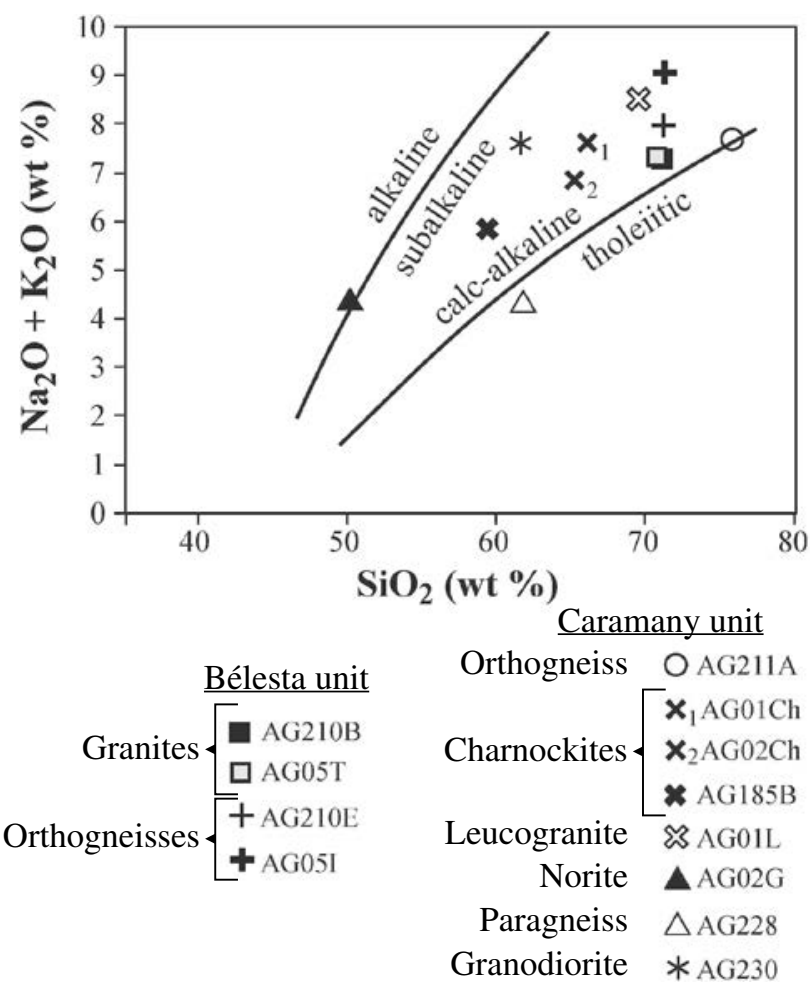

Fig. $6 \mathrm{Na}_{2} \mathrm{O}+\mathrm{K}_{2} \mathrm{O}$ vs. $\mathrm{SiO}_{2}$ diagram of granites (AG210E and AG05I) and orthogneisses (AG210B and AG05T) of the Bélesta unit; and of opx-bearing granodiorites (charnockites) (AG01Ch, AG02Ch, AG185B), a grt + opx quartzofeldspathic fine-grained rock (AG228), an opx-free granodiorite (AG230), a grt-bearing leucogranite (AG01L), a norite (AG02G) and an orthogneiss (AG211A) of the Caramany unit (open ellipses). Some zircons of AG210J display thin overgrowths yielding Latest Carboniferous ages (at about $300 \mathrm{Ma}$ ). In these rims, $\mathrm{Th} / \mathrm{U}$ ratios are very low, lower than 0.01 , demonstrating their recrystallization, whereas other analyses have mostly typical magmatic $\mathrm{Th} / \mathrm{U}$ ratios higher than 0.1 .

AG210E and AG210G granites have yielded Concordia ages of $298.1 \pm 3.0 \mathrm{Ma}$ (Fig. 8c) and $306.9 \pm 2.7 \mathrm{Ma}$ (Fig. 8d), respectively, i.e., Latest Carboniferous-(Earliest Permian). It is noteworthy that both granites AG210E and AG210G also contain zircon cores and grains yielding consistent Concordia ages at 535.5 $\pm 6.6 \mathrm{Ma}$ and $533.8 \pm 7.2 \mathrm{Ma}$, respectively. These ages are very similar to those of the neighbouring orthogneisses. A few older inherited zircons have been also characterized. A previous dating obtained by multigrains zircon ID-TIMS from a granite of this cross section $(\mathrm{AG} 202=\mathrm{AG} 210 \mathrm{G})$ provided an age of $317 \pm 3 \mathrm{Ma}$ (Olivier et al. 2004). Inheritance and core-rim relationships provided heterogeneous mixed zircon fractions resulting in too old ages. Consequently, this 317 Ma date is meaningless. Another important noticeable point is the lack of any post-Carboniferous overgrowth for all the studied zircons.

\section{The Caramany unit}

According to Berger et al. (1993) this unit, 1200-1500 m thick, is also mainly composed of Late Proterozoic quartzofeldspathic paragneisses ('Caramany gneisses'), with the exception of two plutonic intrusions, the 'Ansignan charnockite' (Fonteilles 1976; Andrieux 1982; Respaut and Lancelot 1983; Delay 1990; Althoff et al. 1994; Vielzeuf 1996; Olivier et al. 2008) and the 'Cassagnes granite' (Berger et al. 1993), both attributed to the Carboniferous. The following data will provide new constraints to discuss this interpretation.

\section{Petrostructural description of the Caramany unit}

It is difficult to observe continuous cross sections in the Caramany unit (Fig. 2). The following lithological column may be reconstituted: the clearly paraderived formations are represented, in the basal parts, by some tens of metres of marbles and calc-silicate-bearing paragneisses, which may be attributed to the Canaveilles series, dated as Ediacaran in the easternmost part of the Pyrenees (Castiñeiras et al. 2008; Casas et al. 2015; Padel et al. 2017). Some tens of metres of a leucocratic orthogneiss with abundant lens-shaped K-feldspars (AG211A, AG211B) also constitute the lower part of the unit. Grt $\pm b t \pm$ opx-bearing quartzofeldspathic finegrained rocks generally strongly foliated and/or mylonitized (AG228), the so-called 'Caramany gneisses' (Fonteilles 1976; Delay 1990; Fonteilles et al. 1993), form, at various 


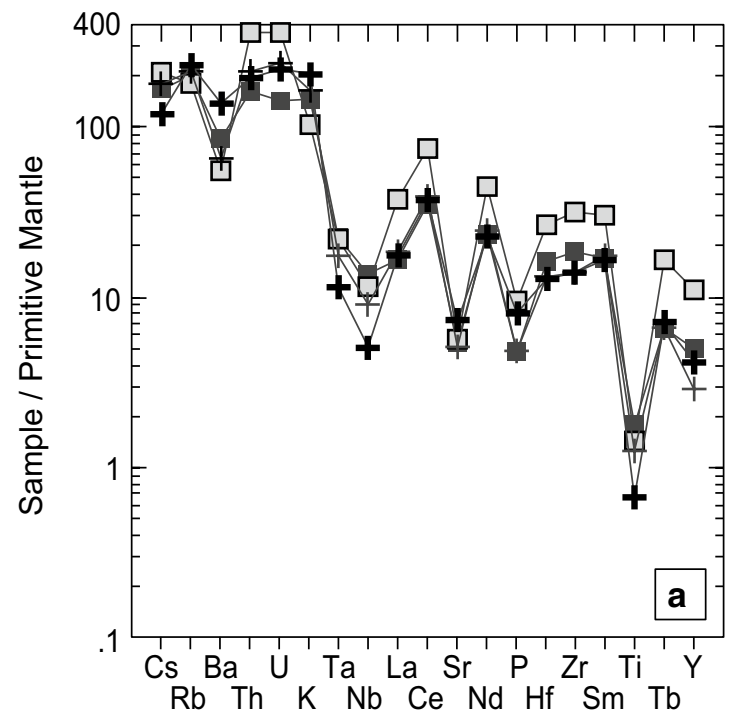

Orthogneisses $\left\{\begin{array}{l}\square \text { AG210B } \\ \square \text { AG05T }\end{array}\right.$

Fig. 7 a Multi-element patterns normalized to the primitive mantle (Wood et al. 1979) for the granite (AG210E and AG05I) and orthogneiss (AG210B and AG05T) samples of the Agly dam cross section in the Bélesta unit. b REE patterns normalized to chondrite (Sun and

levels, a large part of the Caramany unit and are more difficult to interpret and to date ("Discussion"). An 800 m-thick laccolith of hypersthene-bearing granodiorite (Ansignan charnockite) (AG36, AG01Ch, AG02Ch) and generally concordant metre-thick sills of a garnet-bearing leucogranite (AG01L, AG37) with no or rare solid-state deformation represent most of the western part of the unit. Locally, some metres to tens of metres (up to $90 \mathrm{~m}$ near Trilla) of a finegrained, generally concordant, norite (AG02G) are associated with these rocks. The contact between the laccolith and its country rock, especially the orthogneisses and the calc-silicate-bearing paragneisses, is intrusive magmatic. A few $\mathrm{km}$ to the east of Ansignan, in the Caramany area, some metre-thick sills of charnockite (AG185B, AG185D) and grt-bearing leucogranite (AG185E) may represent the lateral equivalent of the Ansignan laccolith but, although the magmatic texture is still visible, these rocks are rather strongly mylonitized. Lastly, a porphyritic granodiorite without opx (AG230), more or less mylonitic, the 'Cassagnes granite', forms a pluri-metre-thick sill in the upper part of the Caramany unit.

A brief description of the thin sections corresponding to the samples dated in this study, and some other samples typical of this unit, is given in Table 1. Microphotographs of Fig. 9 show the main facies of the Caramany unit. AG211A orthogneiss shows a typical gneissic texture with recrystallized quartz, eventually with chess-board extinction, biotite

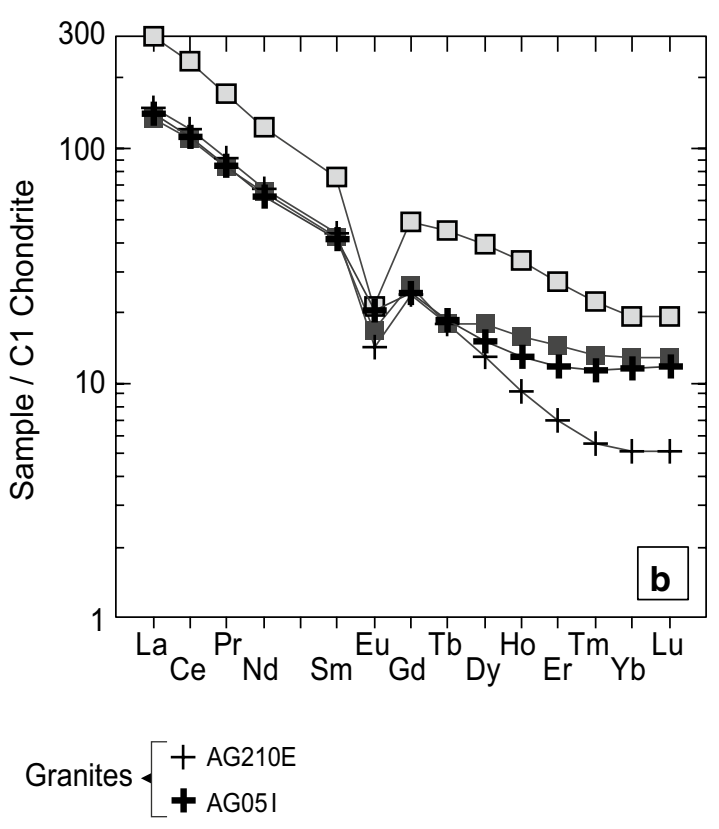

McDonough 1989) for the granite (AG210E and AG05I) and orthogneiss (AG210B and AG05T) samples of the Agly dam cross section in the Bélesta unit

is also recrystallized and forms rare continuous bands or is located in pressure shadows at the extremities of the stretched garnets. The AG228 rock shows quartz ribbons and more or less strongly stretched K-feldspars, garnets and orthopyroxenes due to the mylonitization. AG36 charnockite displays a magmatic texture with undeformed minerals. In AG185B charnockite the quartz forms small ribbons typical of mylonitic deformation and all minerals are more or less deformed. AG230 granodiorite shows recrystallized biotite forming continuous bands, stretched porphyroblasts of $\mathrm{K}$-feldspars and small ribbons of quartz indicating a strong mylonitization.

\section{Chemical composition of gneisses and granitoids of the Caramany unit}

Eight samples (see location in Fig. 1b) from this unit were analyzed for major and trace elements (Table 2). The orthogneiss (AG211A) plots, on the Shand diagram (Fig. 10) in the peraluminous rocks area, near the peraluminous/metaluminous boundary $(\mathrm{A} / \mathrm{CNK}=1)$, and around the I-type/S-type granites boundary $(\mathrm{A} / \mathrm{CNK}=1.1)$, like the orthogneisses and granites of the Bélesta unit (Fig. 5). The magmatic charnockite (AG01Ch, close to AG36, and AG02Ch) and a leucogranite (AG01L) associated with this charnockite, the mylonitized charnockite (AG185B) and the Cassagnes granodiorite (AG230), plot near the same boundaries but with higher A/ 

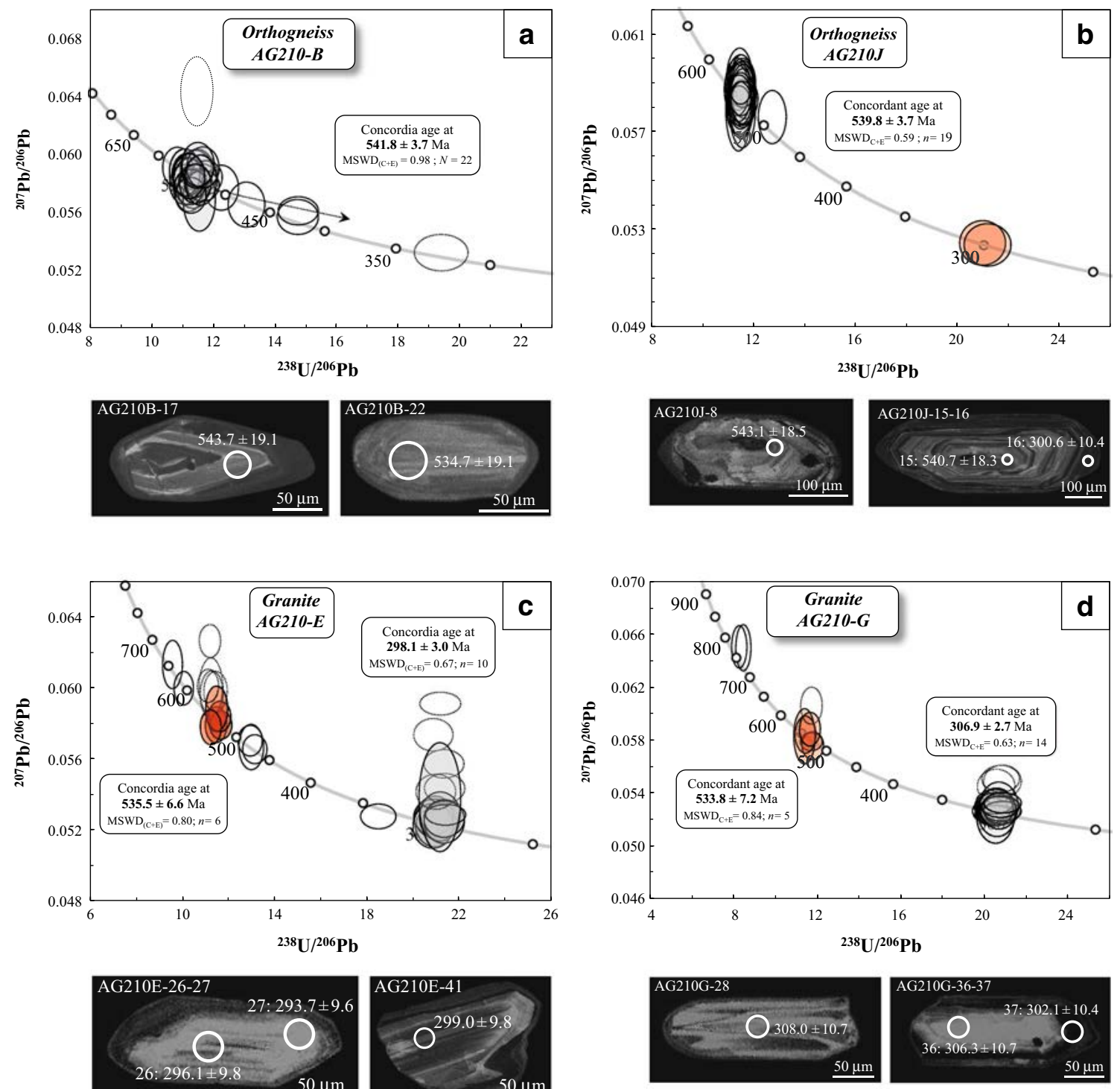

Fig. $8{ }^{207} \mathrm{~Pb} /{ }^{206} \mathrm{~Pb}$ vs. ${ }^{238} \mathrm{U} /{ }^{206} \mathrm{~Pb}$ Concordia diagram for the orthogneiss (AG210B and AG210J) and granite (AG210E and AG210G) samples of the Agly dam cross section in the Bélesta unit

Table 3 Summary of the datings obtained in this study

\begin{tabular}{lllll}
\hline & Sample & Coordinates & Rock type & Age (Ma) \\
\hline Bélesta unit & AG210E & $42^{\circ} 44^{\prime} 43^{\prime \prime} \mathrm{N}, 2^{\circ} 35^{\prime} 15^{\prime \prime} \mathrm{E}$ & Granite & $298.1 \pm 3.0 ;(535.5 \pm 6.6)$ \\
& AG210G & $42^{\circ} 44^{\prime} 42^{\prime \prime} \mathrm{N}, 2^{\circ} 35^{\prime} 16^{\prime \prime} \mathrm{E}$ & Granite & $306.9 \pm 2.7 ;(533.8 \pm 7.2)$ \\
& AG210B & $42^{\circ} 44^{\prime} 43^{\prime \prime} \mathrm{N}, 2^{\circ} 35^{\prime} 15^{\prime \prime} \mathrm{E}$ & Orthogneiss & $541.8 \pm 3.7$ \\
& AG210J & $42^{\circ} 44^{\prime} 42^{\prime \prime} \mathrm{N}, 2^{\circ} 35^{\prime} 17^{\prime \prime} \mathrm{E}$ & Orthogneiss & $539.8 \pm 3.7$ \\
& AG36 & $42^{\circ} 45^{\prime} 12^{\prime \prime} \mathrm{N}, 2^{\circ} 29^{\prime} 48^{\prime \prime} \mathrm{E}$ & Charnockite & $306.9 \pm 2.5$ \\
& AG185B & $42^{\circ} 44^{\prime} 05^{\prime \prime} \mathrm{N}, 2^{\circ} 34^{\prime} 09^{\prime \prime} \mathrm{E}$ & Charnockite & $298.6 \pm 2.7 ;(313.9 \pm 2.9)$ \\
& AG228 & $42^{\circ} 43^{\prime} 59^{\prime \prime} \mathrm{N}, 2^{\circ} 34^{\prime} 35^{\prime \prime} \mathrm{E}$ & Paragneiss & $299.0 \pm 4.3$ \\
& AG230 & $42^{\circ} 43^{\prime} 19^{\prime \prime} \mathrm{N}, 2^{\circ} 35^{\prime} 48^{\prime \prime} \mathrm{E}$ & Granodiorite & $308.1 \pm 3.4$ \\
& AG211A & $42^{\circ} 45^{\prime} 18^{\prime \prime} \mathrm{N}, 2^{\circ} 31^{\prime} 30^{\prime \prime} \mathrm{E}$ & Orthogneiss & $528.5 \pm 4.7$ \\
\hline
\end{tabular}

Bélesta unit: AG210E and AG210G granites; AG210B and AG210J orthogneisses; Caramany unit: AG36 magmatic charnockite; AG185B mylonitic charnockite; AG228 partially melted and mylonitic grt + opxbearing quartzofeldspathic rock; AG230 mylonitic opx-free granodiorite ('Cassagnes granite'); AG211A orthogneiss 
Fig. 9 Microphotographs of the dated rocks of the Caramany unit : the orthogneiss (AG211A) shows a typical gneissic texture with recrystallized quartz, eventually with chess-board extinction, and recrystallized biotite; the mylonitized grt + opx quartzofeldspathic rock (AG228) shows quartz ribbons and rather strongly deformed $\mathrm{Kfs}$, grt and opx; the charnockite (AG36) displays a magmatic texture with undeformed minerals; in the charnockite (AG185B) the quartz forms small ribbons typical of mylonitic deformation and all minerals are more or less deformed; the opx-free granodiorite ('Cassagnes granite') (AG230) shows recrystallized biotite forming continuous bands and small ribbons of quartz indicating a strong mylonitization. $b t$ biotite, grt garnet, $K f s \mathrm{~K}$-feldspar, $o p x$ orthopyroxene, $p l$ plagioclase, qtz quartz
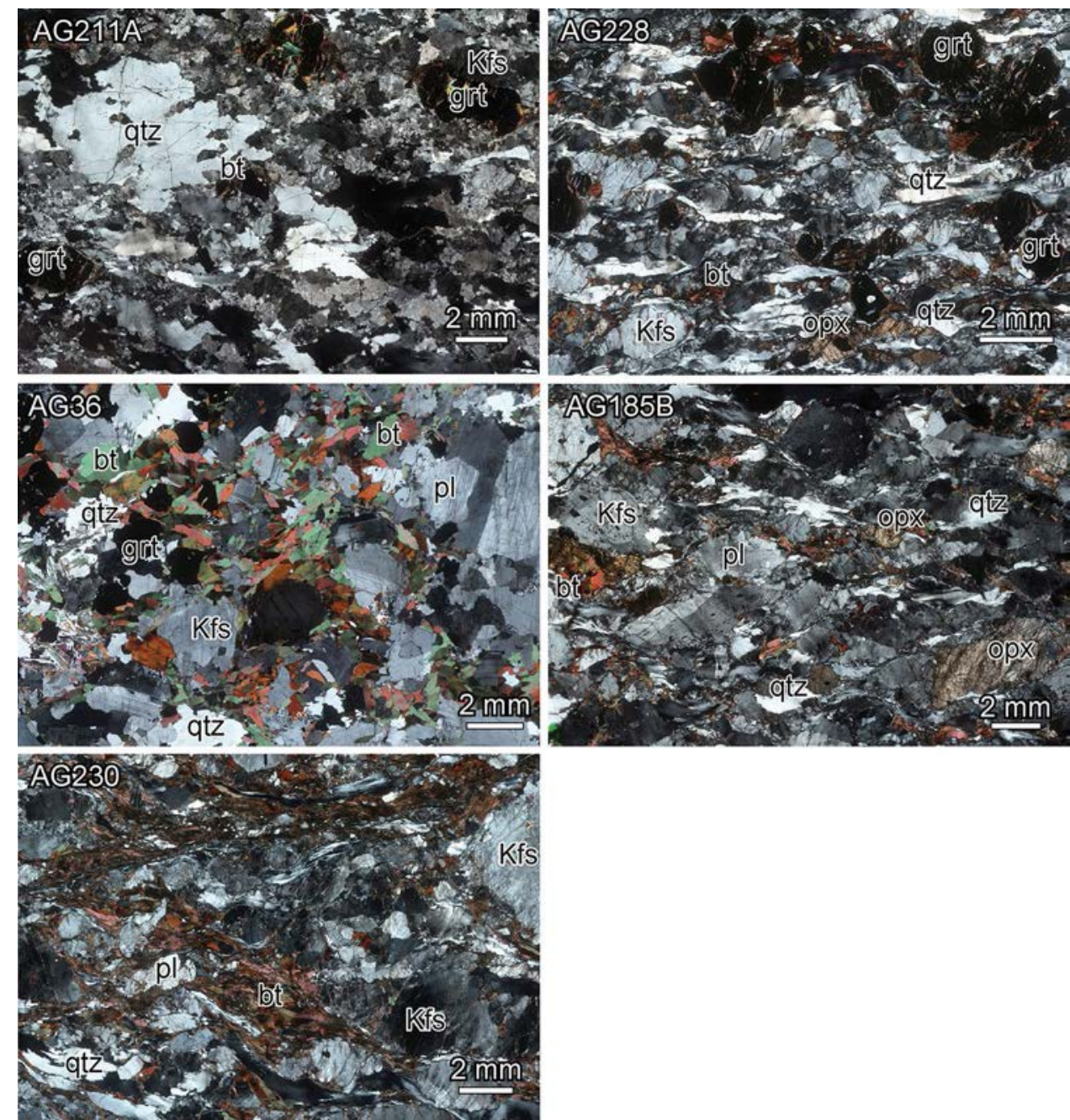

NK ratios. Other samples of the charnockite analyzed by Vielzeuf (1996, p. 459) and Touil et al. (1996) have very similar compositions. The grt + opx-bearing quartzofeldspathic fine-grained rock (AG228) does not plot in the same area and displays much higher $\mathrm{A} / \mathrm{CNK}$ and $\mathrm{A} / \mathrm{NK}$ ratios, because of a rather high content in $\mathrm{Al}_{2} \mathrm{O}_{3}$ (16.28\%); it also shows very low $\mathrm{K}_{2} \mathrm{O}$ content (1.72\%) and high $\mathrm{FeO}$ content (9.23\%). The norite AG02G is characterized by a low A/ $\mathrm{CNK}$ ratio and a high $\mathrm{A} / \mathrm{NK}$ ratio. The multi-element mantle-normalized spectra (Fig. 11a) are rather similar, however, with stronger negative anomalies in $\mathrm{Ta}, \mathrm{Nb}, \mathrm{P}$ and $\mathrm{Ti}$ for the orthogneiss and the grt leucogranite and a negative anomaly in Th for the norite. The REE patterns (Fig. 11b) show two groups of rocks, one group (the orthogneiss, the grt-bearing leucogranite, the norite and the grt + opx-bearing quartzofeldspathic rock) with moderately fractionated $\operatorname{REE}\left([\mathrm{La} / \mathrm{Yb}]_{\mathrm{N}}\right.$ ratios of 3.91, 9.24, 6.20 and 5.31, respectively) and flat heavy REE patterns $\left([\mathrm{Gd} / \mathrm{Yb}]_{\mathrm{N}}=0.82\right.$, $1.24,2.03$ and 1.00, respectively), and the other group (the three charnockite samples and the Cassagnes granodiorite) characterized by more fractionated patterns with $[\mathrm{La} / \mathrm{Yb}]_{\mathrm{N}}$ ratios between 27.72 (one of the two magmatic charnockite) and 87.08 (the mylonitized charnockite), and low concentrations in heavy REE $\left(\mathrm{Yb}_{\mathrm{N}}\right.$ between 3.21 for one magmatic charnockite and 10.28 for the other one).

On a $\mathrm{Na}_{2} \mathrm{O}+\mathrm{K}_{2} \mathrm{O}$ vs. $\mathrm{SiO}_{2}$ diagram (Fig. 6), all the plutonic rocks of the Caramany unit here analyzed belong to the calc-alkaline-(subalkaline) domain, like the plutonic rocks of the Bélesta unit.

\section{$\mathrm{U} / \mathrm{Pb}$ dating of rocks from the Caramany unit}

The U-Pb diagrams are reported in Fig. 12. Samples AG36 (magmatic charnockite), AG185B (mylonitized charnockite), AG228 (mylonitized grt + opx-bearing quartzofeldspathic rock), and AG211A (porphyritic orthogneiss) have been dated by U/Pb on separated zircons. AG230 ('Cassagnes granite') has been dated by $\mathrm{U} / \mathrm{Pb}$ on zircons in petrographic thin section during the same session. 

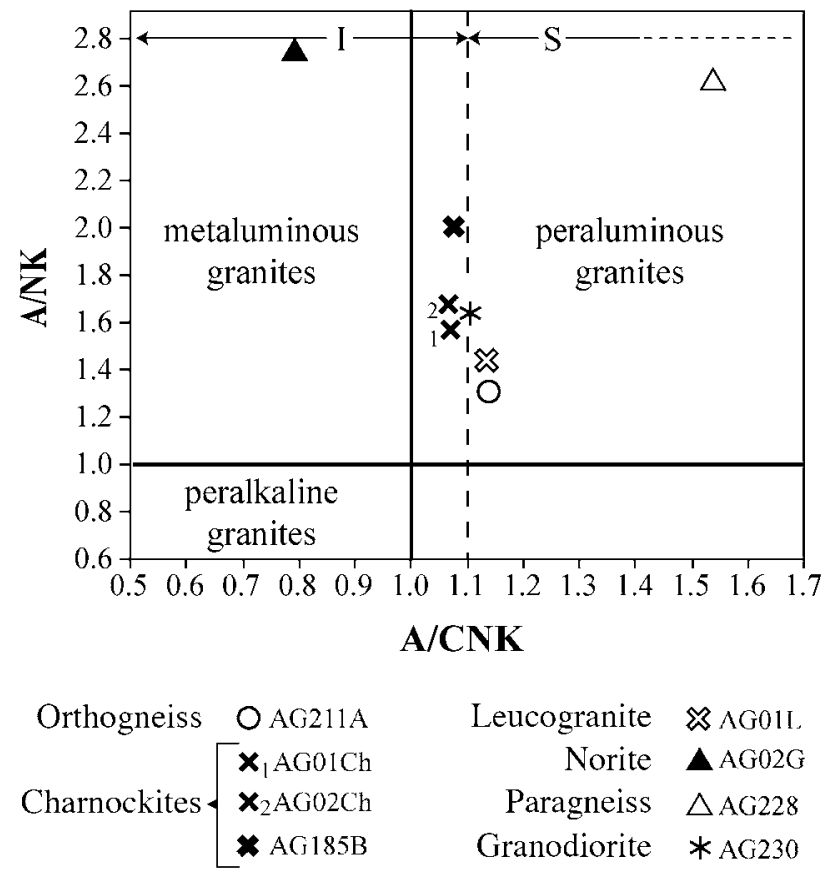

ages mostly between $1000 \mathrm{Ma}$ and about $300 \mathrm{Ma}$ and generally discordant. Two discordant cores provide apparent ages as old as $3.4 \mathrm{Ga}$ and $1.8 \mathrm{Ga}$. Moreover, the zircons of this sample are not euhedral but rounded. Considering the youngest analytical points, a Concordia age at 299.0 \pm 4.3 Ma can be calculated (Fig. 12e). The latter is similar to the ages of the plutonic rocks mentioned above. This dating result and the chemical composition of this sample (see above), lead us to interpret this rock as a partially melted paragneiss. The peraluminous granites above dated which form a large part of the Caramany unit probably derived from the recycling and remelting of older sources such as this paragneiss.

\section{Discussion}

\section{Reinterpretation of the composition of the Bélesta and Caramany units}

Our new data, mostly the geochronological dates (summarized in Table 3), lead us to deeply reinterpret the composition and significance of the two units constituting the deepest part of the Agly massif. We especially show the importance of the Cambrian and Carboniferous plutonisms which are illustrated in Fig. 13, a crucial point for reconstructing the crustal evolution of this part of the Pyrenees during the Paleozoic.

The cross section of the Bélesta unit displays about the same proportion (ca. 15\%) of paragneisses and Late Carboniferous granites, whereas the Earliest Cambrian orthogneisses are dominant (ca. 70\%). The paragneisses may be interpreted as the country rocks of the orthogneisses and consequently they are Precambrian in age. All these rocks display parallel contacts, undisturbed by the slight mylonitization of the unit, and consequently both the orthogneisses and granites may be similarly interpreted as sills. Our results about the nature and relative proportions of the rocks were obtained from a 50 m-long cross section only. However, the orthogneisses are generally dominant everywhere in this unit, the amount of granite is limited and the paragneisses are only represented by few metrethick sillimanite-rich thin gneisses. Very locally, the Precambrian paraderived rocks are also represented by some metres of calc-silicate-bearing paragneisses (and not many levels of such paragneisses as represented erroneously, instead of mylonitic bands, on the Rivesaltes geological map, Fonteilles et al. 1993). The series is locally migmatized, as it is in the dam cross section, but in most places the various rock types may be unambiguously identified. Consequently, we consider that the cross section studied here gives a good approximation of the relative proportion of the three main rocks constituting the Bélesta unit. The thickness of the Bélesta unit (1000 m) estimated by 


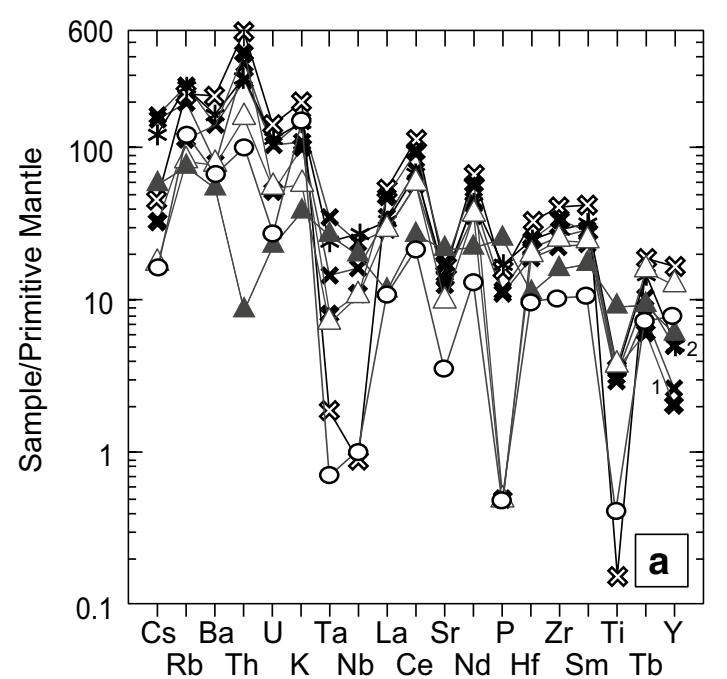

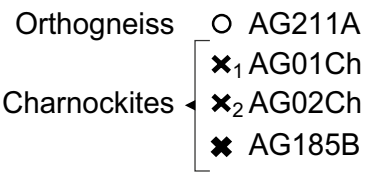

Fig. 11 a Multi-element patterns normalized to the primitive mantle (Wood et al. 1979) for an orthogneiss (AG211A), two magmatic charnockites [AG01Ch (1) and AG02Ch (2)], a mylonitized charnockite (AG185B), a magmatic grt-bearing leucogranite (AG01L), a magmatic norite (AG02G), a mylonitized grt +opx-bearing quartzofeldspathic rock (AG228) and a mylonitized opx-free granodiorite ('Cassagnes granite') (AG230) of the Caramany unit. b REE

Berger et al. (1993) seems to be slightly underestimated as our cross section (Fig. 2, cross section $\mathrm{AA}^{\prime}$ ) indicates a thickness of $1200 \mathrm{~m}$. Consequently, the Earliest Cambrian orthogneisses represent more than $800 \mathrm{~m}$, and the Carboniferous plutonic rocks represent a present-day thickness of about $200 \mathrm{~m}$ in the Bélesta unit.

The proportion of the various rocks constituting the Caramany unit is more difficult to estimate, because continuous cross sections are rare. The Precambrian calc-silicate paragneisses and marbles crop out in many places but they are never thicker than some tens of metres, as are the Early Cambrian augen-orthogneisses. The grt \pm opx-bearing quartzofeldspathic rocks, that we have interpreted as paragneisses, could be hundreds of metres thick. They must be Precambrian in age, because the paragneisses of the overlying Bélesta unit are Precambrian. The Carboniferous plutonic rocks, the opx-bearing granodiorite, i.e., charnockite, the grt-bearing leucogranite, the norite and the Cassagnes granodiorite, represent about $900 \mathrm{~m}$. The thickness of the Caramany unit (1200-1500 m) given by Berger et al. (1993) seems to have been underestimated by these authors. From the cross sections $\mathrm{AA}^{\prime}$ and $\mathrm{BB}^{\prime}$ drawn in Fig. 2a presentday total thickness of $3000 \mathrm{~m}$ seems to be more correct, the

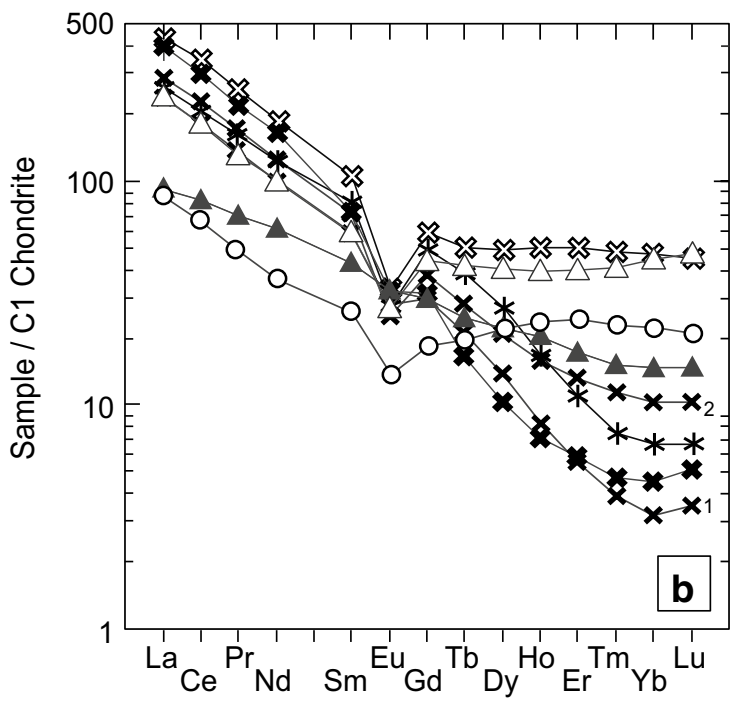

\author{
Leucogranite $\rtimes$ AG01L \\ Norite $\triangle A G 02 G$ \\ Paragneiss $\triangle A G 228$ \\ Granodiorite * AG230
}

patterns normalized to chondrite (Sun and McDonough 1989) for an orthogneiss (AG211A), two magmatic charnockites [AG01Ch (1) and AG02Ch (2)], a mylonitized charnockite (AG185B), a magmatic grt-bearing leucogranite (AG01L), a magmatic norite (AG02G), a mylonitized grt + opx-bearing quartzofeldspathic rock (AG228) and a mylonitized opx-free granodiorite ('Cassagnes granite') (AG230) of the Caramany unit

Carboniferous plutonic rocks representing about $30 \%$ of this unit, especially in its lower part.

\section{Timing and mode of emplacement of plutonic rocks during the Paleozoic in the Pyrenean crust}

The following stages of plutonism have been identified in this part of the Pyrenean crust, either from the data obtained in this study or from previous studies. This is schematically represented in Fig. 13 which was not drawn to scale, because we cannot estimate the original volume of the granites constituting the protolith of the orthogneisses, nor the proportion of the orthogneisses and paragneisses recycled to form the Carboniferous granitoids.

\section{Earliest Cambrian}

Numerous metre-thick sills of calc-alkaline porphyritic granites, representing hundreds of metres of present-day total thickness, were emplaced at about $540 \mathrm{Ma}$ in the Precambrian metasedimentary series of the future Bélesta unit. Pluri-metre thick sills of porphyritic granites were emplaced at about $530 \mathrm{Ma}$ at the base of the Precambrian 

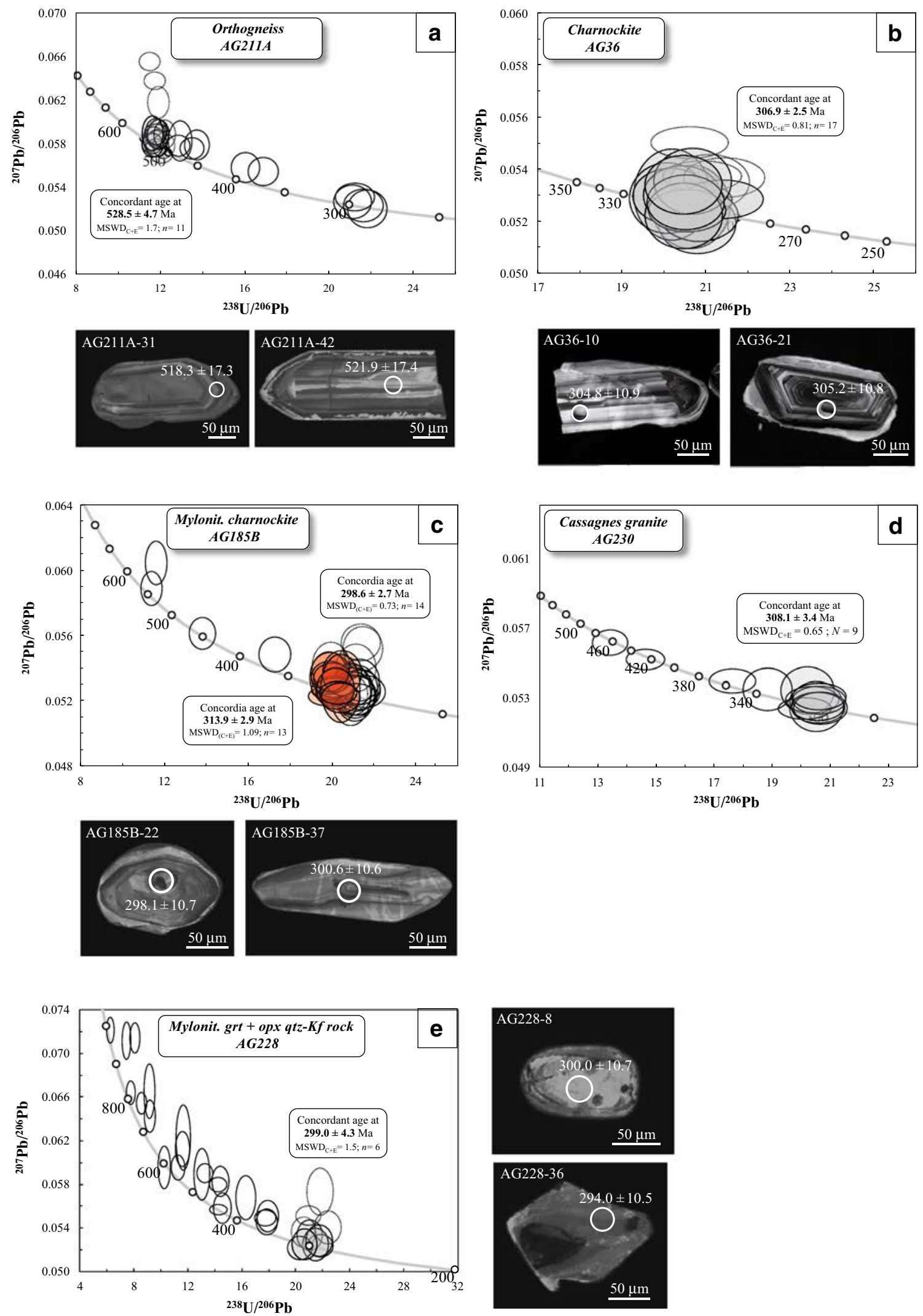

Fig. $12{ }^{207} \mathrm{~Pb} /{ }^{206} \mathrm{~Pb}$ vs. ${ }^{238} \mathrm{U} /{ }^{206} \mathrm{~Pb}$ Concordia diagram for an orthogneiss (AG211A), a magmatic charnockite (AG36), a mylonitized charnockite (AG185B), a mylonitized opx-free granodiorite ('Cas-

sagnes granite') (AG230) and a mylonitized grt +opx-bearing quartzofeldspathic rock (AG228) from the Caramany unit 
Fig. 13 Schematic evolution of the plutonic inputs in the middle to upper crust of the North Pyrenean Agly Massif during the Paleozoic (not to scale)

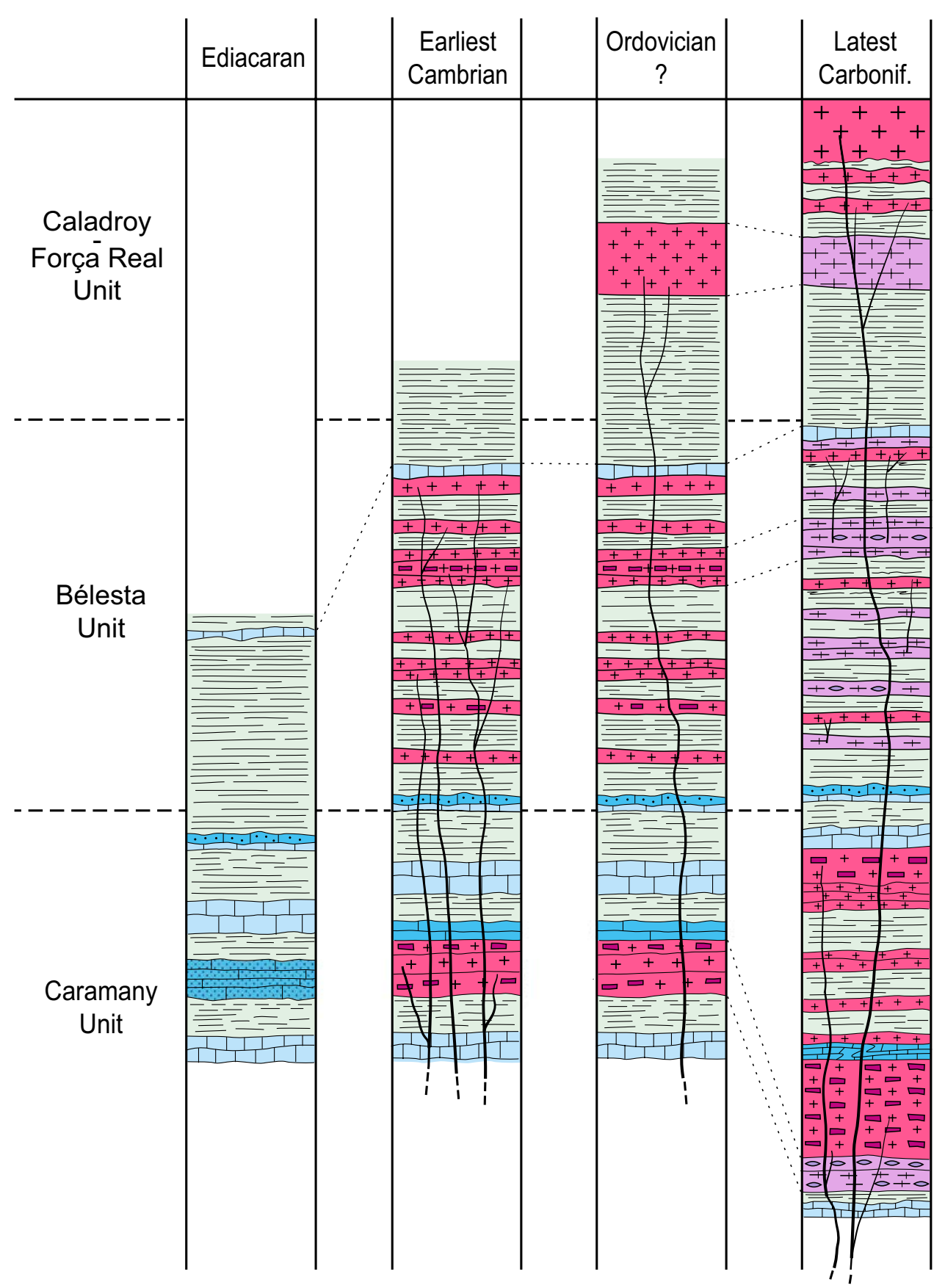

Limestones / Marbles

Calcar. sandstones / Calc-silicate paragneisses

Pelites / Aluminous paragneisses

$\psi$ Feeder dykes

++ Granites $\square+$ Porphyritic granites $+\square+\infty$ Orthogneisses metasedimentary series of the future Caramany unit. Because of the analytical uncertainties, we are not able to determine whether theses ages correspond to a single or several plutonic events.

Cambrian plutonic rocks were almost unknown in other North Pyrenean massifs, except a mylonite possibly derived from a granitic rock dated at $526 \pm 7 \mathrm{Ma}$ and an augen gneiss dated at $506 \pm 12 \mathrm{Ma}$ from the St-Barthélemy North Pyrenean massif (Delaperrière et al. 1994).

In the Aston gneiss dome, located in the central part of the Axial Zone of the Pyrenees, Mezger and Gerdes (2016) have dated a Latest Neoproterozoic (ca. $545 \mathrm{Ma}$ ) biotite 
metagranite, in an unclear position among orthogneisses of Middle Ordovician age (ca. $467 \mathrm{Ma}$ ) constituting the major part of the gneiss core. Slightly older plutonism has been characterized by Castiñeiras et al. (2008) from the eastern part of the axial zone of the Pyrenees, where two Ediacaran orthogneisses have been dated, the Port gneiss ( $553 \pm 4 \mathrm{Ma}$ ) and the Mas Blanc gneiss (560 Ma $\pm 7 \mathrm{Ma}$ ). Volcanic events dated in the 580-530 Ma time span have been characterized in the same domain (Castiñeiras et al. 2008; Casas et al. 2015; Laumonier et al. 2015; Padel et al. 2017). According to these data it seems that the volcanic activity started earlier and ended later than the plutonic activity in the eastern Pyrenees. However, our results point to a plutonic activity longer than the $560-553$ Ma time span admitted by Castiñeiras et al. (2008), because it lasted at least until about $530 \mathrm{Ma}$ and was particularly important in volume at the beginning of the Cambrian time. The previous data also support the conclusion of Laumonier et al. (2004) and Castiñeiras et al. (2008) that no Cadomian basement could be characterized in the Pyrenees.

Though Cambrian plutonic rocks are well characterized in the Pyrenees only in the Agly North Pyrenean massif through our study, various Cambrian plutonic rocks are known in the neighbouring French Massif Central, especially in the 520-530 Ma time span (Ducrot et al. 1979; Melleton et al. 2010; Faure et al. 2010), i.e., coeval with the porphyritic granites of the Caramany unit. 545-540 Ma old orthogneisses, i.e., coeval with the orthogneisses of the Bélesta unit, have been recently characterized in the eastern Massif Central (Chelle-Michou et al. 2017; Couzinié et al. 2017). The Agly Massif is located in the North Pyrenean zone, which shows many similarities with the axial zone of the Pyrenees and also with the Montagne Noire (southern part of the Massif Central) which could have been rather close at the Precambrian-Cambrian boundary, probably on the northern Gondwana margin (e.g., Raumer et al. 2015). Was all this magmatism related to the southward subduction of the Panthalassic ocean under this margin, or to a back-arc activity is a question still unresolved.

\section{Ordovician (?)}

We have not characterized any Ordovician plutonic rock in the Caramany and Bélesta gneissic units. However, the protolith of the Riverole orthogneiss emplaced as a ca. 800 m-thick laccolith at the base of the probably Cambrian-Lower Ordovician micaschists overlying these units, and consequently younger than these micaschists, could be Ordovician in age by comparison with several Early to Middle Ordovician (mostly in the 477-467 Ma time span) more or less similar orthogneisses (e.g., the Peyregrand orthogneiss in the Aston massif) that have been dated in the Pyrenees during the past decades, as for example in the Canigou dome (Barbey et al. 2001; Deloule et al. 2002; Cocherie et al. 2005), in the Roc de France/Frausa dome (Cocherie et al. 2005), at the Cap de Creus (Castiñeiras et al. 2008) and in the Aston and Hospitalet domes (Denèle et al. 2009; Mezger and Gerdes 2016). Many Ordovician (471-450 Ma time span) orthogneisses have also been characterized in the neighbouring Montagne Noire (Roger et al. 2004; Cocherie et al. 2005; Pitra et al. 2012).

The Ordovician geodynamic context was characterized by opening of various oceanic domains to the north of the Gondwana continent (review in Paquette et al. 2017). The emplacement of the numerous Ordovician granitic laccoliths in the Pyrenees, such as, possibly, the Riverole one in the Agly Massif, and in the Montagne Noire was probably related to these extensional events.

\section{Latest Carboniferous}

Various plutonic rocks from both the Caramany and Bélesta units have yielded Late to Latest Carboniferous ages, between 298 and $308 \mathrm{Ma}$. The partial melting suffered by various rocks of these units was certainly coeval with this plutonic event as suggested by the $299 \mathrm{Ma} \pm 4 \mathrm{Ma}$ age obtained on a paragneiss from the Caramany unit. No difference in age appears between the plutonic rocks from one or another unit, though they are rather different chemically, the plutonic rocks from the Caramany unit being generally more mafic and aluminous than the granitoids from the Bélesta unit.

The new age obtained in this paper on the magmatic charnockite ( $307 \pm 3 \mathrm{Ma}$ ) is close to the ages (308-304 Ma time span) obtained for the crystallization of the Saint-Arnac pluton by Olivier et al. $(2004,2008)$ (see Geological setting). This indicates that the Carboniferous plutonic rocks of this part of the Pyrenees crust were emplaced in a restricted time span, in the order of $10 \mathrm{Ma}$. The age of this plutonic event is in good agreement with the mean age, ca. $304 \mathrm{Ma}$, calculated by Denèle et al. (2014) from all the published emplacement ages of the large plutons of the Pyrenees, both in the Axial and North Pyrenean zones. Therefore, the date of $314 \pm 7 / 6$ Ma obtained by Respaut and Lancelot (1983) for the charnockite laccolith appears slightly older although compatible with the lower limit of the uncertainty.

The plutonic rocks of the Caramany and Bélesta units have suffered, after their emplacement, a local and variable HT mylonitization to ultra-mylonitization, as did some rocks of the overlying Caladroy-Força Real unit, especially pegmatites which are the most recent plutonic rocks of the Agly Massif. These pegmatites have not been dated but similar pegmatites of the Cap de Creus, in the Axial Zone, have been recently dated in a $302 \pm 4$ to $296 \pm 3$ Ma time span i.e., Latest Carboniferous-Earliest Permian (Van Lichtervelde et al. 2017). This HT mylonitization, which produced a 
strong thinning of the series, could have occurred shortly after the emplacement of the pegmatites.

A noticeable point is the lack of any post-Carboniferous overgrowth for all the studied zircons, either from the Bélesta unit or from the Caramany unit, this meaning that these minerals have not registered the Eo-Alpine (Cretaceous) HT metamorphism.

The position of the Pyrenees during the Late Carboniferous, and the position of the North Pyrenean domain with respect to the domain of the future axial zone, are not clearly established (e.g., Martínez Catalán 2011; Stampfli et al. 2013; Denèle et al. 2014). The origin of the numerous calc-alkaline plutons emplaced at that time in the upper parts of both domains (Fig. 1a) may be related to a subduction zone which could correspond to the subduction of the Paleo-Tethys under the northeastern part of Gondwana, as represented by Kroner and Romer (2013), and postulated by Pereira et al. (2014) and Druguet et al. (2014). The structural studies of these Late Carboniferous granites have shown that they were emplaced in a dextral transpressional regime (Gleizes et al. 1998). Our results about the importance of Carboniferous plutonism in deep levels of the Pyrenean crust address again the question of the position and significance of this domain during the Variscan orogeny.

\section{Appraisal of the Paleozoic plutonism in the North Pyrenean Agly Massif}

A precise balance of the Paleozoic plutonic inputs in this part of the Pyrenean crust from the Earliest Cambrian to the Latest Carboniferous is difficult to establish. We have seen that at least three phases of emplacement of hundreds of metres of plutonic rocks (one-or more?-during the Earliest Cambrian, one possibly during the Ordovician, one during the Latest Carboniferous) occurred at various levels of the crust during this 240 Ma period. We have also seen that a part of these plutonic rocks very likely resulted from a recycling of older partially melted plutonic rocks, as suggested by the age of zircon cores of the Carboniferous granites of the Bélesta unit coeval with the Cambrian orthogneisses constituting the country rocks of these granites, and also by the very similar chemical compositions of these orthogneisses and granites. Recycling of Precambrian aluminous metasedimentary rocks affected by the migmatization in the formation of the plutonic rocks is also very likely. In other words, at each phase of plutonic rocks emplacement in the lithologic column, a part of the preexisting rocks were consumed. Because we have not evidenced arguments for a juvenile crustal growth by a mantle contribution, recycling of rocks from various levels of the Pyrenean crust would be the main process for the plutonic evolution of this crust during the Paleozoic.
Despite these restrictions for estimating precisely the plutonic transfers in the Agly crust the following facts have been evidenced by our study:

- The total thickness of plutonic rocks intruded in this part of the Pyrenean crust was very important, especially during the Earliest Cambrian and the Latest Carboniferous. This last event corresponds to the emplacement in a rather short time of several thousands of metres of recycled crustal material all along the lithologic column represented by the three units of the Agly Massif. This must have induced important constraints on the thermal evolution of the Pyrenean crust characterized by an HTLP metamorphism, the so-called 'basement effect' proposed by Fonteilles and Guitard (1964).

- The plutonic rocks were intruded as sills and laccoliths in the gneissic units and at the base of the CaladroyForça Real micaschist unit during each period. Only the plutonic rocks of the upper part of the crust have formed large plutons (Saint-Arnac pluton). This mode of sill emplacement is also known at the base of the Saint-Laurent-La Jonquera (Olivier et al. 2016) and Mont-LouisAndorre (Denèle et al. 2014) large plutons in the eastern part of the Axial Zone of the Pyrenees.

\section{Conclusions}

This study provides many new data about the various events of emplacement of plutonic rocks which occurred during the Paleozoic in the Pyrenees. We especially show the importance of the Earliest Cambrian plutonic event, almost unknown until now, in the formation of the Pyrenean crust, characterized by multi-injections of metre-scale sills. This is certainly not a specificity of the Agly Massif and coeval plutonic rocks will probably be found in other deep domains of this chain. Our results also confirm the volumetric importance of the Latest Carboniferous plutonism especially through sills' emplacement in the middle crust, coeval with the emplacement of large plutons in shallower levels.

Dating precisely the Carboniferous HT-LP metamorphism will be necessary to know whether it is coeval or not with the plutonism that we have contributed to characterize and to better understand the relationships between both phenomena.

Acknowledgements We are greatly indebted to P. Barbey, G. Gleizes, B. Laumonier, P. Micoud and O. Vanderhaeghe for discussions about a previous version of this paper. We also thank $\mathrm{Ph}$. Goncalves and E. Druguet for their critical reviews. We thank Ch. Cavaré for drawings, J.-F. Mena for thin sections, and D. Baratoux for providing us chemical analyses of samples AG05E, AG05I and AG05T, and photographs of the Agly dam cross section. This work is a contribution to the 
'Référentiel géologique français' program and was grant-aided by the Bureau de Recherches Géologiques et Minières (BRGM).

\section{References}

Althoff F, Barbey P, Pons J (1994) La charnockite d'Ansignan et le granite de Saint-Arnac, témoins d'une extension crustale d'âge hercynien dans le massif de l'Agly (Pyrénées-Orientales, France). C R Acad Sci Paris 319-II:239-246

Andrieux P (1982) Conditions de cristallisation et évolution paragénétique d'une charnockite hercynienne: le complexe granulitique d'Ansignan (massif de l'Agly, Pyrénées-Orientales). Bull Miner Paris 105:253-266

Barbey P, Cheilletz A, Laumonier B (2001) The Canigou orthogneisses (Eastern Pyrenees, France, Spain): an Early Ordovician rapakivi granite laccolith and its contact aureole. C R Acad Sci Paris 332:129-136

Berger GM, Fonteilles M, Leblanc D, Clauzon G, Marchal JP, Vautrelle C (1993) Notice explicative, carte géologique de France à 1/50 000, feuille Rivesaltes (1090). BRGM, Orleans, p 119

Casas JM, Navidad M, Castiñeiras P, Liesa M, Aguilar C, Carreras J, Hofmann M, Gärtner A, Linnemann U (2015) The Late Neoproterozoic magmatism in the Ediacaran series of the Eastern Pyrenees: new ages and isotope geochemistry. Int J Earth Sci (Geol Rundsch) 104:909-925

Castiñeiras P, Navidad M, Liesa M, Carreras J, Casas JM (2008) U$\mathrm{Pb}$ zircon ages (SHRIMP) for Cadomian and Early Ordovician magmatism in the Eastern Pyrenees: new insights into the preVariscan evolution of the northern Gondwana margin. Tectonophysics 461:228-239

Chelle-Michou C, Laurent O, Moyen JF, Block S, Paquette JL, Couzinié S, Gardien V, Vanderhaeghe O, Villaros A, Zeh A (2017) Pre-Cadomian to late-Variscan odyssey of the eastern Massif Central, France: formation of the West European crust in a nutshell. Gondwana Res 46:170-190

Cocherie A, Baudin T, Autran A, Guerrot C, Fanning CM, Laumonier $\mathrm{B}$ (2005) U-Pb zircon (ID-TIMS and SHRIMP) evidence for the early ordovician intrusion of metagranites in the late Proterozoic Canaveilles Group of the Pyrenees and the Montagne Noire (France). Bull Soc Geol Fr 176-3:269-282

Couzinié S, Laurent O, Poujol M, Mintrone M, Chelle-Michou C, Moyen JF, Bouilhol P, Vezinet A, Marko L (2017) Cadomian S-type granites as basement rocks of the Variscan belt (Massif Central, France): implications for the crustal evolution of the north Gondwana margin. Lithos 286-287:16-34

Delaperrière E, Saint Blanquat M de, Brunel M, Lancelot J (1994) Géochronologie U-Pb sur zircons et monazites dans le massif du Saint Barthélemy (Pyrénées, France): discussion des âges des événements varisques et pré-varisques. Bull Soc Geol Fr 165-2:101-112

Delay F (1990) Le massif nord-pyrénéen de l'Agly (Pyrénées Orientales). Evolution tectono-métamorphique. Exemple d'un amincissement crustal polyphasé. Soc Géol Nord, Publication 17, Villeneuve d'Ascq, vol 3, pp 34, 152, 393

Deloule E, Alexandrov P, Cheilletz A, Laumonier B, Barbey P (2002) In situ U-Pb zircon ages for Early Ordovician magmatism in the Eastern Pyrenees, France: the Canigou orthogneisses. Int J Earth Sci (Geol Rundsch) 91:398-405

Denèle Y, Barbey P, Deloule E, Pelleter E, Olivier Ph, Gleizes G (2009) Middle Ordovician U-Pb age of the Aston and Hospitalet orthogneissic laccoliths: their role in the Variscan evolution of the Pyrenees. Bull Soc Geol Fr 180-3:209-216

Denèle Y, Laumonier B, Paquette JL, Olivier Ph, Gleizes G, Barbey P (2014) Timing of granite emplacement, crustal flow and gneiss dome formation in the Variscan segment of the Pyrenees. Geol Soc Lond Spec Publ 405:265-287

Druguet E, Castro A, Chichorro M, Pereira MF, Fernández C (2014) Zircon geochronology of intrusive rocks from Cap de Creus, Eastern Pyrenees. Geol Mag 151:1095-1114

Ducrot J, Lancelot JR, Reille JL (1979) Datation en Montagne Noire d'un témoin d'une phase majeure d'amincissement crustal caractéristique de l'Europe prévarisque. Bull Soc Geol Fr 21(4):501-505

Faure M, Cocherie A, Bé Mézème E, Charles N, Rossi Ph (2010) Middle Carboniferous crustal melting in the Variscan belt: new insights from $\mathrm{U}-\mathrm{Th}-\mathrm{Pbtot}$. monazite and $\mathrm{U}-\mathrm{Pb}$ zircon ages of the Montagne Noire axial zone (southern French Massif Central). Gondwana Res 18:653-673

Fonteilles M (1976) Essai d'interprétation des compositions chimiques des roches d'origines métamorphique et magmatique du massif hercynien de l'Agly (Pyrénées orientales). Thèse Université de Paris VI, p 685

Fonteilles M, Guitard G (1964) L' effet de socle dans le métamorphisme hercynien de l'enveloppe paléozoïque des gneiss des Pyrénées. C R Acad Sci Paris 258:4299-4302

Fonteilles M, Leblanc D, Clauzon G, Vaudin JL, Berger GM (1993) Carte géologique de la France (1/50 000), feuille Rivesaltes (1090). BRGM, Orleans

Gleizes G, Leblanc D, Bouchez JL (1998) The main phase of the Hercynian orogeny in the Pyrenees is a dextral transpression. In: Holdsworth RE, Strachan RA, Dewey JF (eds) Continental transpressional and transtensional tectonics, vol 135. Geol Soc London, Special Publications, pp 267-273

He XF, Santosh M (2014) Crustal recycling through intraplate magmatism: evidence from the trans-North China Orogen. J Asian Earth Sci 95:147-163

Hurai V, Paquette JL, Huraiová M, Konečný P (2010) Age of deep crustal magmatic chambers in the intra-Carpathian back-arc basin inferred from LA-ICPMS U-Th-Pb dating of zircon and monazite from igneous xenoliths in alkali basalts. J Volcan Geotherm Res 198:275-287

Jackson SE, Pearson NJ, Griffin WL, Belousova EA (2004) The application of laser ablation-inductively coupled plasma-mass spectrometry to in situ $\mathrm{U}-\mathrm{Pb}$ zircon geochronology. Chem Geol 211(1-2):47-69

Kroner U, Romer RL (2013) Two plates-many subduction zones: the Variscan orogeny reconsidered. Gondwana Res 24:298-329

Lardeaux JM (2014) Deciphering orogeny: a metamorphic perspective. Examples from European Alpine and Variscan belts. Part II: Variscan metamorphism in the French Massif Central-a review. Bull Soc Geol Fr 185(5):281-310

Laumonier B, Autran A, Barbey P, Cheilletz A, Baudin T, Cocherie A, Guerrot C (2004) Conséquences de l'absence de socle cadomien sur l'âge et la signification des séries pré-varisques (antéOrdovicien supérieur) du sud de la France (Pyrénées, Montagne Noire). Bull Soc Geol Fr 175:105-117

Laumonier B, Calvet M, Le Bayon B, Barbey P, Lenoble JL (2015) Notice explicative de la feuille Prats-de-Mollo-La-Preste à 1/50 000. BRGM Éditions, Service géologique national, pp 189

Linnemann U, Pereira F, Jeffries TE, Drost K, Gerdes A (2008) The Cadomian Orogeny and the opening of the Rheic Ocean: The diacrony of geotectonic processes constrained by LA-ICP-MS U-PB zircon dating (Ossa-Morena and Saxo-Thuringian Zones, Iberian and Bohemain Massifs). Tectonophysics 461:21-43

Ludwig K (2001) User's manual for Isoplot/Ex version 2.49, a geochronological toolkit for Microsoft Excel, Special Publication 1a. Berkeley Geochronological Center, Berkeley, p 55

Martínez Catalán JR (2011) Are the oroclines of the Variscan belt related to late Variscan strike-slip tectonics? Terra Nova 23:241-247 
Melleton J, Cocherie A, Faure M, Rossi Ph (2010) Precambrian protoliths and Early Paleozoic magmatism in the French Massif Central: $\mathrm{U}-\mathrm{Pb}$ data and the North Gondwana connection in the west European Variscan belt. Gondwana Res 17:13-25

Mezger JE, Gerdes A (2016) Early Variscan (Visean) granites in the core of central Pyrenean gneiss domes: implications from laser ablation $\mathrm{U}-\mathrm{Pb}$ and $\mathrm{Th}-\mathrm{Pb}$ studies. Gondwana Res 29:181-198

Moyen JF, Laurent O, Chelle-Michou C, Couzinié S, Vanderhaeghe O, Zeh A, Villaros A, Gardien V (2017) Collision vs. subductionrelated magmatism: two contrasting ways of granite formation and implications for crustal growth. Lithos 277:154-177

Olivier Ph, Gleizes G, Paquette JL (2004) Gneiss domes and granite emplacement in an obliquely convergent regime: New interpretation of the Variscan Agly Massif (Eastern Pyrenees, France). In: Whitney DL, Teyssier C, Siddoway CS (eds) Gneiss domes in orogeny, vol 380, pp 229-242 (Geol Soc Am Spec Pap)

Olivier Ph, Gleizes G, Paquette JL, Muñoz Sáez C (2008) Structure and $\mathrm{U}-\mathrm{Pb}$ dating of the Saint-Arnac pluton and the Ansignan charnockite (Agly Massif): a cross-section from the upper to the middle crust of the Variscan Eastern Pyrenees. J Geol Soc London 165:141-152

Olivier Ph, Druguet E, Castaño LM, Gleizes G (2016) Granitoid emplacement by multiple sheeting during Variscan dextral transpression: the Saint-Laurent-La Jonquera pluton (Eastern Pyrenees). J Struct Geol 82:80-92

Padel M, Álvaro JJ, Casas JM, Clausen S, Poujol M, Sánchez-García $\mathrm{T}$ (2017) Cadomian volcanosedimentary complexes across the Ediacaran-Cambrian transition of the Eastern Pyrenees, southwestern Europe. Int J Earth Sci. https://doi.org/10.1007/s0053 1-017-1559-5

Paquette JL, Piro JL, Devidal JL, Bosse V, Didier A (2014) Sensitivity enhancement in LA-ICP-MS by $\mathrm{N}_{2}$ addition to carrier gas: application to radiometric dating of U-Th-bearing minerals. Agil ICP MS J 58:4-5

Paquette JL, Ballèvre M, Peucat JJ, Cornen G (2017) From opening to subduction of an oceanic domain constrained by LA-ICP-MS $\mathrm{U}-\mathrm{Pb}$ zircon dating (Variscan belt, Southern Armorican Massif, France). Lithos 294-295:418-437

Pereira MF, Castro A, Chichorro M, Fernández C, Díaz-Alvarado J, Martí J, Rodríguez C (2014) Chronological link between deepseated processes in magma chambers and eruptions: PermoCarboniferous magmatism in the core of Pangaea (Southern Pyrenees). Gondwana Res 25:290-308

Pitra P, Poujol M, Van Den Driessche J, Poilvet JC, Paquette JL (2012) Early Permian extensional shearing of an Ordovician granite: the Saint-Eutrope 'C/S-like' orthogneiss (Montagne Noire, French Massif Central). C R Géosci 344:377-384
Raumer JF von, Stampfli GM, Arenas R, Sánchez Martínez S (2015) Ediacaran to Cambrian oceanic rocks of the Gondwana margin and their tectonic interpretation. Int J Earth Sci (Geol Rundsch) 104:1107-1121

Respaut JP, Lancelot JR (1983) U/Pb dating on zircons and monazites of the synmetamorphic emplacement of the Ansignan charnockite (Agly Massif-France). Neues Jahrb Miner Abh 147-1:21-34

Roger F, Respaut JP, Brunel M, Matte P, Paquette JL (2004) Première datation $\mathrm{U}-\mathrm{Pb}$ des orthogneiss œillés de la zone axiale de la Montagne noire (Sud du Massif central): nouveaux témoins du magmatisme ordovicien dans la chaîne Varisque. C R Géosci $336: 19-28$

Safonova I (2017) Juvenile versus recycled crust in the Central Asian Orogenic belt: implications from ocean plate stratigraphy, blueschist belts and intra-oceanic arcs. Gondwana Res 47:6-27

Stampfli GM, Hochard C, Vérard C, Wilhem C, Raumer J von (2013) The formation of Pangea. Tectonophysics 593:1-19

Sun SS, McDonough WF (1989) Chemical and isotopic systematics of oceanic basalts: implications for mantle composition and processes. In: Sanders AD, Norry MJ (eds) Magmatism in the ocean basins, vol 42, pp 313-345 (Geol Soc Lond Spec Publ)

Touil A, Garcia D, Fonteilles M (1996) Diversité chimique du matériel basique associé aux granitoïdes: le massif d'Ansignan (Pyrénées Orientales varisques, France). C R Acad Sci Paris 322-IIa:25-32

Van Achterbergh E, Ryan C, Jackson S, Griffin W (2001) Data reduction software for LA-ICP-MS. In: Sylvester P (ed) Laser ablation-ICPMS in the Earth science. Mineralogical Association of Canada, Québec, pp 239-243

Van Lichtervelde M, Grand'Homme A, Saint-Blanquat M de, Paquette OPh,GA, Melgarejo JL, Druguet JC, Alfonso E P (2017) U-Pb geochronology on zircon and columbite-group minerals of the Cap de Creus pegmatites, NE Spain. Miner Pet 111:1-21

Vielzeuf D (1984) Relations de phases dans le faciès granulite et implications géodynamiques. L'exemple des granulites des Pyrénées. Doctorate thesis, Clermont-Ferrand University, p 288

Vielzeuf D (1996) Les massifs nord-pyrénéens à soubassement granulitique. In: Barnolas A, Chiron JC (eds) Synthèse géologique et géophysique des Pyrénées. Introduction. Géophysique. Cycle hercynien, vol 1. BRGM-ITGE, Orleans, pp 502-521

Wiedenbeck M, Allé P, Corfu F, Griffin WL, Meier M, Oberli F, Quadt A von, Roddick JC, Spiegel W (1995) Three natural zircon standards for U-Th-Pb, Lu-Hf, trace element and REE analyses. Geostand Newslett 19(1):1-23

Wood DA, Joron JL, Treuil M (1979) A re-appraisal of the use of trace elements to classify and discriminate between magma series erupted in different tectonic settings. Earth Planet Sci Lett $45: 326-336$ 